\title{
Clinical outcomes and risk factors for COVID-19 among migrant populations in high-income countries: A systematic review
}

\author{
Sally E Hayward ${ }^{\mathrm{a}, \mathrm{o}}$, Anna Deal ${ }^{\mathrm{a}, \mathrm{o}}$, Cherie Cheng ${ }^{\mathrm{a}}$, Alison Crawshaw ${ }^{\mathrm{a}}$, Miriam Orcutt ${ }^{\mathrm{b}}$, \\ Tushna F Vandrevala ${ }^{\mathrm{c}}$, Marie Norredam ${ }^{\mathrm{d}}$, Manuel Carballo ${ }^{\mathrm{e}}$, Yusuf Ciftci ${ }^{\mathrm{f}}$, \\ Ana Requena-Méndez ${ }^{g}$, Christina Greenaway ${ }^{\mathrm{h}}$, Jessica Carter ${ }^{\mathrm{a}}$, Felicity Knights ${ }^{\mathrm{a}}$, \\ Anushka Mehrotra $^{a}$, Farah Seedat ${ }^{k}$, Kayvan Bozorgmehr ${ }^{i}$, Apostolos Veizis ${ }^{j}$, \\ Ines Campos-Matos ${ }^{1}$, Fatima Wurie ${ }^{\mathrm{m}}$, Martin McKee $^{\circ}$, Bernadette Kumar ${ }^{\mathrm{n}}$, Sally Hargreaves ${ }^{\mathrm{a}, *}$, \\ on behalf of the ESCMID Study Group for Infections in Travellers and Migrants (ESGITM)
}

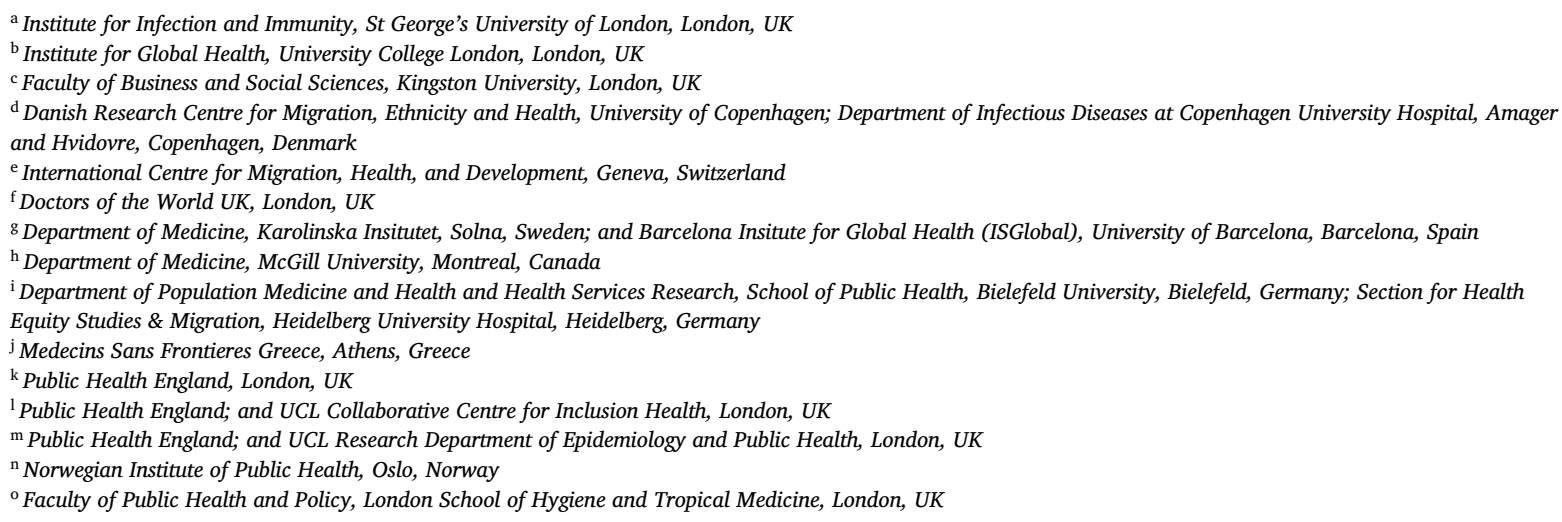

\section{A B S T R A C T}

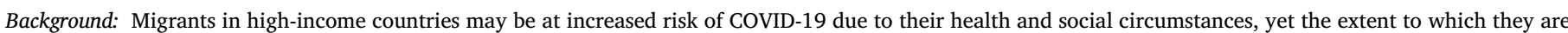

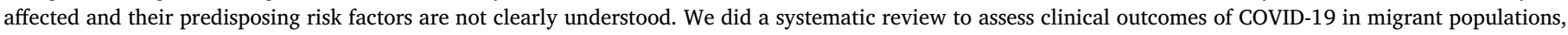
indirect health and social impacts, and to determine key risk factors.

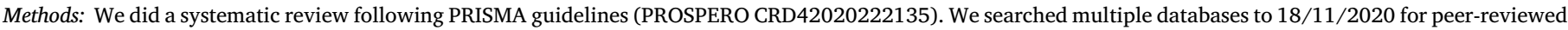

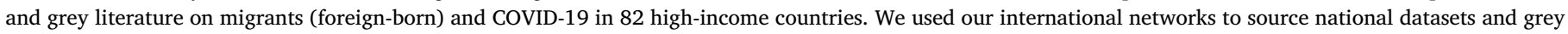

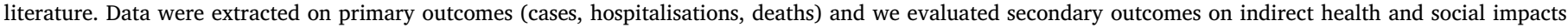
and risk factors using narrative synthesis.

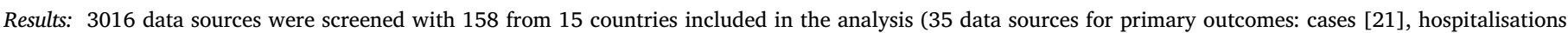

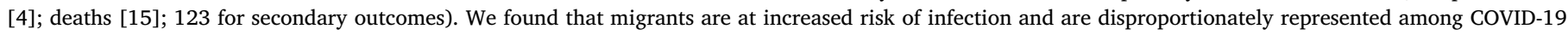

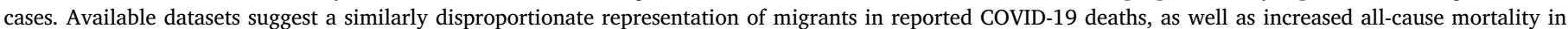

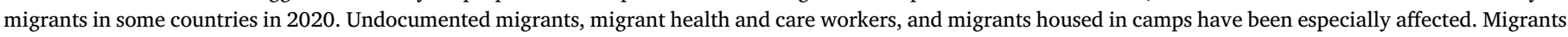

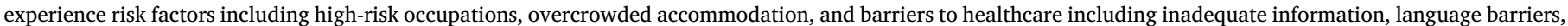
and reduced entitlement.

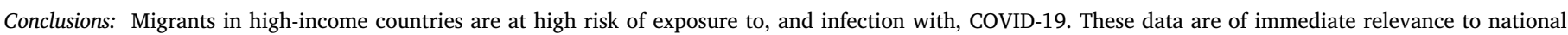

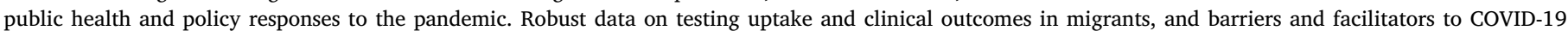
vaccination, are urgently needed, alongside strengthening engagement with diverse migrant groups.

\footnotetext{
* Corresponding author.

E-mail address: s.hargreaves@sgul.ac.uk (S. Hargreaves).
} 


\section{Introduction}

The COVID-19 pandemic has highlighted the vast ethnic, social, economic and cultural diversity that has come to characterise contemporary high-income countries (HICs), and has served as a reminder of the growing rate of population movement between, as well as within, countries and the new public health opportunities and challenges this is presenting. One of these challenges is the scale of health and social disparities associated with this diversity, with profound consequences for some ethnic minority groups (Greenaway et al., 2020). Data from several countries have revealed a much greater risk of infection and adverse outcomes from COVID-19 among Black, Asian, and Minority Ethnic [BAME] groups, South/East Asian, Black Americans, Hispanics, Latinos, racialised groups, people of colour, and indigenous groups compared to the native white population in the same countries (Sze and Nevill, 2020). These adverse outcomes are likely the result of a complex interaction of socioeconomic disadvantage influencing exposure to SARS-CoV-2 and underlying health status, that predisposes to severe illness (Public Health England 2020, Mathur et al., 2020), leading to calls to address the root causes of these inequalities now and in the future.

Although a picture is emerging, there is not yet a comprehensive overview of the extent to which migrants (defined as foreign-born) - including refugees, asylum seekers, labour migrants, and undocumented migrants living temporarily or permanently in different HICs - have been impacted by COVID-19, and their specific risk factors. Prior to the COVID-19 pandemic, global migration was at its highest level on record, with 1 billion people on the move around the world, and with HICs receiving unprecedented numbers of people seeking human security either through political asylum and/or work opportunities (Abubakar and Devakumar, 2018). Most of the relatively few health datasets with information on ethnicity currently used to monitor COVID-19 reflect what information is already recorded by healthcare systems (which is highly variable across countries and regions). For the most part these fail to capture migration status, combining those born in the host countries to families that may have been in the country for several generations with more recent migrants, thus failing to reflect the health dynamics of contemporary migration. Although more recently arrived migrants predominantly from low- and middle-income countries, are typically considered to be young and healthy on arrival (Aldridge and Nellums, 2018), and may share many of the characteristics of "older" generation ethnic minorities and their offspring, they may also present a unique spectrum of health and social risk factors for COVID-19 exposure and infection that to date has been poorly defined. In many countries, migrants make up a significant proportion of front-line workers who may have a greater exposure to COVID-19, in sectors witnessing a disproportionate impact of COVID-19 infections (Nicholson and Alulema, 2020). There are, in addition, tens of thousands of migrants in HICs who are being housed in camps, detention centres, and labour dormitories or compounds, all of which are considered high-risk environments for COVID-19. Recent analyses suggest that countries and regions with large migrant populations (including US, Italy, Spain, France, and the UK) should ensure they are better considered in public health responses (Guadagno, 2020, Migration Data Portal 2020).

In order to develop a more targeted and inclusive public health response a better understanding of the impact that COVID-19 is having specifically on migrant populations is critically needed. We therefore did a systematic review to explore and assess what is currently known about clinical outcomes of COVID-19 (cases, hospitalisations, deaths), indirect health and social impacts, and to identify key risk factors and vulnerabilities in migrant populations.

\section{Methods}

\subsection{Search strategy}

We undertook a systematic review in line with the Preferred Reporting Items for Systematic Reviews and Meta-Analyses (PRISMA) guidelines (Moher et al., 2009), and registered with PROSPERO (CRD42020222135). We searched the following databases: Embase, Web of Science, Oxford Academic Journals, PubMed NIH, Clinical Trials, China CDC MMWR, CDC reports, ProQuest Central (Proquest), CINAHL, Africa Wide Information (Ebsco), Scopus, PsycInfo, CAB Abstracts, Global Health, J Stage, Science Direct, Wiley Online Journals, JAMA Network, British Medical Journal, Mary Ann Liebert, New England Journal of Medicine, Sage Publications, Taylor and Francis Online, Springer Link, Biomed Central, MDPI, ASM, PLOS, The Lancet, Cell Press, and pre-print sites chemRxiv, SSRNbioRxiv, and medRxiv facilitated through the WHO Global Research on COVID-19 database from inception to 18/11/2020 (https://search.bvsalud.org/global-literatureon-novel-coronavirus-2019-ncov/). The latter is a daily-updated, multilingual resource of all the global literature (peer-reviewed literature, pre-prints and grey literature) pertaining to COVID-19. We used a broad search strategy encompassing terms related to ethnicity and migrants, to source specific information pertaining to migrants (Appendix 1).

Records were imported into EndNote, and duplicates deleted. Title/abstract and full-text screening were carried out by two reviewers using Rayyan QCRI (Ouzzani et al., 2016). A snowballing method was used to follow up potentially relevant articles cited in included papers. Grey literature sources were also hand-searched. Our international networks were used to directly engage migrant health experts in key countries, who were specifically approached to source country-level public health data (via the Ministry of Health and public health statistics) and other grey literature.

\subsection{Selection criteria and primary/secondary outcomes}

We included any data pertaining to our selected primary and secondary outcomes on migrant populations from 82 World Bank HICs (countries listed in Appendix 2). Migrants were defined as foreign-born individuals, born outside of the country in which they are resident. Primary outcomes were clinical outcomes of COVID-19 in migrant populations (cases, hospitalisation, deaths). Secondary outcomes included indirect health and social impacts, and risk factors and vulnerabilities (co-morbidities, health behaviours and systemic factors, social and cultural factors, and occupation).

No restrictions were imposed on study design because our preliminary scoping review revealed that in this rapidly evolving field important data were often embedded into letters, editorials, and grey literature as well as primary research studies and national statistics. We imposed no language restrictions and information was translated where required. Studies were excluded if it was not possible to determine whether individual(s) in the population studied were migrants, based on the stated criteria, and where data were collected outside of the countries listed or did not directly relate to COVID-19 outcomes, impacts and risk factors. We excluded all mass media reports.

\subsection{Data extraction, critical appraisal and synthesis}

Abstracts were screened and data were extracted in duplicate at each stage, involving three researchers (CC, SEH, SH). Records and data were managed through EndNote and Excel databases prepared by the principal reviewers. The quality of studies was assessed by two reviewers (AD, CC), using Joanna Briggs Institute critical appraisal tools (checklists for cohort studies, qualitative research, prevalence studies, cross-sectional studies, case series or text and opinion checklists, as appropriate for the individual study design) (Joanna Briggs Institute 2020). Quality scores were calculated as a total out of the maximum number of applicable questions and converted into percentages. Studies with a score of 80 $100 \%$ were considered high quality, $60-79 \%$ medium quality and 0 $59 \%$ low quality. Data sources were not excluded based on study quality, but information on quality contributed to the meta-synthesis and discussion. Only original research was appraised for both primary and secondary outcomes, as the appraisal tools are specific for study designs 

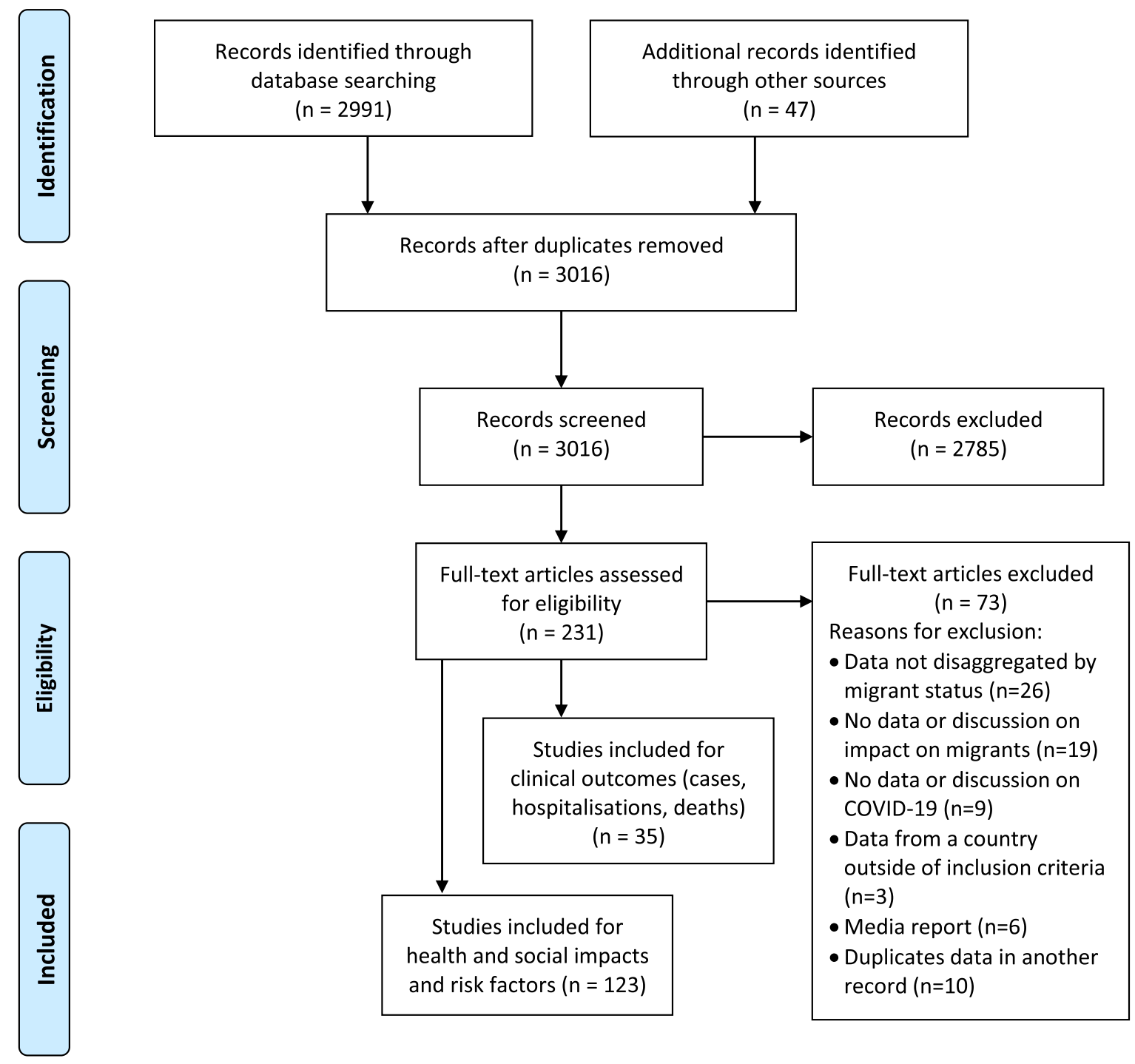

Fig. 1. PRISMA flow diagram of included data sources.

and thus are not applicable to sources such as commentaries. Critical appraisals were only performed for literature in English, French or Spanish, due to the language restrictions of the critical appraisal team.

For the primary outcomes we included only primary data sources; the heterogeneity of study designs and populations precluded meta-analysis. For the secondary outcomes we included primary data and data from other sources, which was collated and assessed using narrative synthesis.

\subsection{Patient and public involvement}

The authorship of this paper includes a migrant representative member of St George's University of London Migrant Health Project Advisory Group, as well as several professionals working directly with migrants to implement COVID-19-related interventions. These individuals have been involved in all stages of this research.

\section{Results}

Initial searches of databases and for grey literature identified 3016 records to screen; 158 of which were included in the final analysis (35 for primary outcomes, 123 for secondary outcomes) (Fig. 1). Supplementary Table 1 details the characteristics of all included data sources.
We found 35 data sources reporting on our primary clinical outcomes in migrants, including 21 on cases (Guttmann et al., 2020, Sundaram et al., 2020, Kim et al., 2020, Norweigan Institute of Public Health [Folkehelseinstituttet] 2020a, Norweigan Institute of Public Health [Folkehelseinstituttet] 2020b, Swedish Public Health Agency (Folkhälsomyndigheten) 2020, Statens Serum Institut 2020, Statens Serum Institut 2020, Guijarro et al., 2020, Grilli et al., 2020, Strully et al., 2020, Jaqueti Aroca et al., 2020, Chew et al., 2020, Alkhamis et al., 2020, Openshaw and Travassos, 2020, European Centre for Disease Prevention and Control 2020, Ministry of Health Singapore 2020, Ministry of Health Saudi Arabia 7 May 2020, Buda et al., 2020, Bozorgmehr et al., 2020), 4 on hospitalisations (Statens Serum Institut 2020, Giorgi Rossi et al., 2020, Hamadah and Behbehani, 2020, Fabiani et al., 2020), and 15 on mortality (Public Health England 2020, Statens Serum Institut 2020, Giorgi Rossi et al., 2020, Hamadah and Behbehani, 2020, Fabiani et al., 2020, Canevelli et al., 2020, Papon and Robert-Bobée, 2020, Observatoire Regional de Sante Ile de France 2020, Kunst et al., 2020, Hansson et al., 2020, Calderón-Larrañaga et al., 2020, Drefahl et al., 2020, Rostila et al., 2020, Centrum for epidemiologi och samhallsmediccin RS 2020, Cook et al., 2020). This includes data from Sweden (6 records), Italy (4), the United States (3), Canada (2), Denmark (2), Spain (2), the UK (2), France (2), Kuwait (2), Singapore (2), Norway (2), Germany (2), the Netherlands (1), Greece (1), 
Saudi Arabia (1) and across the EU/EEA/UK (1). Sources include peerreviewed journal articles (13 records), pre-prints (3), national statistics (10), and other grey literature (9). A total of 59 studies were subjected to critical appraisal, including 22 primary outcomes and 37 secondary outcomes. Literature ranged in quality, with 28 studies fitting the criteria for high quality studies (80-100\%), 19 for medium quality (60-79\%) and 12 for low quality (0-59\%). The average quality appraisal score was $73.6 \%$, with reports included in the primary outcomes having a slightly higher quality score on average than those included in the secondary outcomes (74.9\% and 72.9\%, respectively). An additional 123 studies reported on indirect impacts of the pandemic on migrants and/or on risk factors for COVID-19 in migrants.

\subsection{Clinical outcomes}

Table 1 summarises included studies on the primary outcome (cases, hospitalisation, deaths).

\subsubsection{COVID-19 cases}

Data that disaggregate COVID-19 incidence and testing uptake by migrant status indicate that migrants account for a disproportionate number of COVID-19 infections despite low rates of testing. In Ontario, Canada, immigrants make up just over $25 \%$ of the population, but accounted for $43.5 \%$ of all COVID-19 cases up until 13 June (Guttmann et al., 2020). Immigrants had lower rates of testing but there was a higher percentage of positive cases in those tested. Refugees had the highest percentage positivity, at $10.4 \%$, compared with $7.6 \%$ among other immigrants, and $2.6 \%$ in the Canadian-born. Migrants and refugees from Central, Western and East Africa, South America, the Caribbean, Southeast Asia and South Asia showed the highest rates of positive cases for COVID-19 (Guttmann et al., 2020). Among all women who tested positive, $36 \%$ were employed as healthcare workers (immigrants and refugees made up $45 \%$ of these positive healthcare workers): $55 \%$ of positive cases were among female migrants in the economic caregiver categories, including 53\% among those from the Philippines, $64 \%$ from Jamaica and $76 \%$ from Nigeria (Guttmann et al., 2020). In another study, living in an area of Ontario with a greater percentage of recently arrived migrants was significantly positively associated with an increased rate of COVID-19 diagnoses (Sundaram et al., 2020).

In the US, a study that reports using language as a surrogate for immigration status (in the absence of routine data collection on migrant status) found that non-English speakers were tested less frequently for COVID-19 (29 February to 31 May) (4.7\% [95\% CI 4.5\%-4.9\%] vs $5.6 \%$ [95\% CI 5.6\%-5.7\%]), with variations across language groups, but were more likely to test positive (18.6\% [95\% CI $16.8 \%-20.4 \%$ ] vs $4.0 \%$ [95\% CI 3.8\%-4.2\%]) (Kim et al., 2020). Fewer years of formal education and a lack of English or French language ability at the time of immigration was associated with lower testing rates and higher percentage positivity among recent adult migrants in Ontario, Canada (Guttmann et al., 2020).

In Norway, migrants made up $19 \%$ of all reported cases in the week starting 16 March, rising to $42 \%$ in the week starting 27 April (Norweigan Institute of Public Health [Folkehelseinstituttet] 2020a). While incidence among the Somali-born was very high until 1 July, in the autumn the risk increased for migrants from Pakistan, Iraq, Afghanistan, Serbia and Turkey (Norweigan Institute of Public Health [Folkehelseinstituttet] 2020b). Similarly in Sweden, during the first peak of the pandemic (13 March to 7 May), 32\% of positive cases were immigrants, despite making up only $19 \%$ of the population (Swedish Public Health Agency (Folkhälsomyndigheten) 2020). The incidence of COVID-19 was highest among migrants from Turkey (753 per 100,000), followed by Ethiopia (742 per 100,000) and Somalia (660 per 100,000). This compares with an incidence of 189 per 100,000 for non-migrants who were born in Sweden for the same time-period (Swedish Public Health Agency (Folkhälsomyndigheten) 2020).
In Denmark, non-Western migrants and their native-born children accounted for $18 \%$ of cases (29 April to 6 May), which was double their share in the Danish population (Statens Serum Institut, 2020). In an later update (7 September), this had risen substantially to migrants accounting for $26 \%$ of cases Statens Serum Institut (2020). Among nonWestern migrants, the COVID-19 incidence rate was 315 per 100,000 compared with 240 per 100,000 for non-Western descendants and 128 per 100,000 among ethnic Danes (29 April to 6 May) (Statens Serum Institut, 2020). Particularly high incidence rates were seen among migrants from Morocco, Pakistan, Somalia and Turkey (Statens Serum Institut 2020, Statens Serum Institut 2020).

In Alcorcón, Spain (to 25 April) the crude incidence rate of COVID19 among migrants was higher than among the host Spanish populations, at 8.71 and 6.51 per 1000 inhabitants respectively $(p<0.001)$ (Guijarro et al., 2020). The relative risk for COVID-19 was elevated in migrants from sub-Saharan Africa (RR 3.66, 95\% CI 1.42-9.41; $p=0.007$ ), the Caribbean (RR 6.35, 95\% CI 3.83-10.55; $p<0.001$ ), and Latin America (RR 6.92, 95\% CI 4.49-10.67; $p<0.001$ ) but not from other regions (Guijarro et al., 2020). Data from a hospital in Madrid up to the second week of April showed no significant differences between migrants and host population in terms of COVID-19 positivity among those tested (52.5\% [136/259] vs 51.4\% [782/1522]). There was also no difference in testing rate (odds ratio [OR] 1.08 95\% CI 0.95-1.24) between migrants and the host population; only $12.5 \%$ of COVID-19 positive migrants were older than 65 years of age, compared to $56.9 \%$ of Spanish citizens who tested positive. Migrants from Latin America had higher positivity rates per 1000 people, compared with the host population and other migrant groups (Jaqueti Aroca et al., 2020).

A US study found that being foreign-born was positively associated with COVID-19 case rate at the county level (data to 28 May; with fully adjusted incidence rate ratio 1.106 , 95\% CI 1.074-1.139; $p<0.01$ ) (Strully et al., 2020).

In Singapore, labour migrants in crowded dormitories have been disproportionately impacted by COVID-19, with over $95 \%$ of confirmed cases (to 19 June) among dormitory-housed migrants; as of 18 Nov, $54,502(95.7 \%)$ of 58,135 all in-country cases of COVID-19 were in migrants residing in dormitories (Ministry of Health Singapore 2020). A study in one isolated dormitory of 5977 migrant workers (mean age 33 years) in an accommodation centre of 13,000 migrants, 1264 tested positive for COVID-19 (between 11 to 19 April) (Chew et al., 2020). Similarly in Saudi Arabia, Ministry of Health Data reported that $75 \%$ of all people in-country who had tested positive for COVID-19 were migrants (to 7 May) (Ministry of Health Saudi Arabia, 2020).

Data on migrants in detention facilities and reception centres suggest these are high-risk settings for COVID-19. In the US, across 52 facilities run by the Department of Homeland Security (DHS)'s Immigration and Customs Enforcement (ICE) agency as of May 2020 more than $50 \%$ of ICE migrant detainees who had been tested were positive (Openshaw and Travassos, 2020). The European Centre for Disease Prevention and Control has also highlighted several examples of COVID19 outbreaks in migrant reception and detention centres in the European Union/European Economic Area (EU/EEA) and the United Kingdom (UK) in a technical report, including Greece, Germany, Malta, The Netherlands, and Portugal, and concludes that whilst there is no evidence to suggest that SARS-CoV-2 transmission is higher amongst migrants and refugees, overcrowding in reception and detention centres may increase their exposure to the disease (European Centre for Disease Prevention and Control 2020).

This is in line with national notification data from Germany where $2.5 \%$ of notified outbreaks up to 11 August (199 of a total of 7864) were reported in refugee centres comprising $7.5 \%(n=4,146)$ of all notified cases during outbreaks $(n=55,141)$ across the country. The average number of cases per outbreak in refugee centres was 20.8, higher than in any other outbreak setting (Buda et al., 2020). A systematic analysis of outbreak reports to 22 May identified 42 outbreaks in refugee reception and district accommodation centres of 11 federal states, with 1781 
Table 1

Data sources included in primary outcomes data, clinical outcomes (cases, hospitalisations, deaths).

\begin{tabular}{|c|c|c|c|c|c|c|c|c|c|}
\hline Authors" & Location & Population & Study design & $\begin{array}{l}\text { Publication } \\
\text { type }\end{array}$ & Study period & Sample size & Methods & Key results & $\begin{array}{l}\text { appraisal } \\
\text { score }(\%)\end{array}$ \\
\hline \multicolumn{10}{|l|}{ COVID-19 cases } \\
\hline $\begin{array}{l}\text { Guttman } \\
\text { (Guttmann et al., } \\
\text { 2020) }\end{array}$ & $\begin{array}{l}\text { Ontario, } \\
\text { Canada }\end{array}$ & $\begin{array}{l}\text { Migrants } \\
\text { and refugees }\end{array}$ & $\begin{array}{l}\text { Population- } \\
\text { based case/ } \\
\text { testing data }\end{array}$ & Grey & To 13 June & $\begin{array}{l}624,386 \\
\text { tested }\end{array}$ & $\begin{array}{l}\text { Rates of COVID- } 19 \text { testing and } \\
\text { percentage positivity in migrants, and } \\
\text { relationship with socioeconomic } \\
\text { factors }\end{array}$ & $\begin{array}{l}\text { Migrants accounted for } 43.5 \% \text { of all COVID-19 cases } \\
\text { but make up just over } 25 \% \text { of the population; } \\
\text { migrants had lower rates of testing but a higher } \\
\text { percentage positivity in those tested (refugees } 10.4 \% \\
\text { positive, other migrants } 7.6 \% \text {, and Canadian-born } \\
2.6 \% \text { ) }\end{array}$ & $6 / 10(60)$ \\
\hline $\begin{array}{l}\text { Sundaram } \\
\text { (Sundaram et al., } \\
\text { 2020) }\end{array}$ & $\begin{array}{l}\text { Ontario, } \\
\text { Canada }\end{array}$ & Migrants & $\begin{array}{l}\text { Spatial } \\
\text { comparison }\end{array}$ & Pre-print & $\begin{array}{l}1 \text { March to } 20 \\
\text { June }\end{array}$ & $\begin{array}{l}25,050 \\
\text { diagnoses }\end{array}$ & $\begin{array}{l}\text { Association between COVID- } 19 \\
\text { diagnosis and percentage of migrants } \\
\text { by area }\end{array}$ & $\begin{array}{l}\text { Living in an area with a greater percentage of } \\
\text { immigrants was positively associated with rate of } \\
\text { COVID-19 diagnosis }\end{array}$ & $8 / 8(100)$ \\
\hline Kim (Kim et al., 2020) & $\begin{array}{l}\text { Washington } \\
\text { DC, USA }\end{array}$ & $\begin{array}{l}\text { Non-English } \\
\text { speakers }\end{array}$ & $\begin{array}{l}\text { Case/testing } \\
\text { data }\end{array}$ & $\begin{array}{l}\text { Peer- } \\
\text { reviewed } \\
\text { publication }\end{array}$ & $\begin{array}{l}29 \text { February to } \\
31 \text { May }\end{array}$ & $\begin{array}{l}562,242 \\
\text { tested }\end{array}$ & $\begin{array}{l}\text { Rates of COVID- } 19 \text { testing and } \\
\text { percentage positivity in non-English } \\
\text { speakers versus English speakers }\end{array}$ & $\begin{array}{l}\text { Non-English speakers were tested less frequently for } \\
\text { COVID-19 (4.7\% vs 5.6\%) but were more likely to } \\
\text { receive a positive result ( } 18.6 \% \text { vs } 4.0 \%)\end{array}$ & $6 / 8(75)$ \\
\hline $\begin{array}{l}\text { Norweigan Institute of } \\
\text { Public Health } \\
\text { (Norweigan Institute } \\
\text { of Public } \\
\text { Health [Folkehelsein- } \\
\text { stituttet] } \\
\text { 2020a) }\end{array}$ & Norway & Migrants & $\begin{array}{l}\text { Population- } \\
\text { based case } \\
\text { data }\end{array}$ & $\begin{array}{l}\text { National } \\
\text { statistics }\end{array}$ & To 4 May & 7,847 cases & $\begin{array}{l}\text { Percentage of reported cases that are } \\
\text { among the foreign-born }\end{array}$ & $\begin{array}{l}\text { Migrants made up } 19 \% \text { of reported cases in week } 12 \\
\text { and } 42 \% \text { in week } 18\end{array}$ & $\mathrm{~N} / \mathrm{A}$ \\
\hline $\begin{array}{l}\text { Norweigan Institute of } \\
\text { Public Health } \\
\text { (Norweigan Institute } \\
\text { of Public } \\
\text { Health [Folkehelsein- } \\
\text { stituttet] } \\
\text { 2020b) }\end{array}$ & Norway & Migrants & $\begin{array}{l}\text { Population- } \\
\text { based case } \\
\text { data }\end{array}$ & $\begin{array}{l}\text { National } \\
\text { statistics }\end{array}$ & To 5 Nov & - & $\begin{array}{l}\text { Incidence rate among migrants by } \\
\text { country of origin versus those born in } \\
\text { Norway }\end{array}$ & $\begin{array}{l}\text { Until } 1 \text { July, incidence among the Somali-born was } \\
\text { very high, but in autumn the risk increased for } \\
\text { migrants from Pakistan, Iraq, Afghanistan, Serbia and } \\
\text { Turkey }\end{array}$ & $\mathrm{N} / \mathrm{A}$ \\
\hline $\begin{array}{l}\text { Swedish Public Health } \\
\text { Agency } \\
\text { (Swedish Public } \\
\text { Health } \\
\text { Agency (Folkhäl- } \\
\text { somyndigheten) } \\
\text { 2020) }\end{array}$ & Sweden & Migrants & $\begin{array}{l}\text { Population- } \\
\text { based case } \\
\text { data }\end{array}$ & $\begin{array}{l}\text { National } \\
\text { statistics }\end{array}$ & $\begin{array}{l}13 \text { March to } 7 \\
\text { May }\end{array}$ & - & $\begin{array}{l}\text { Incidence of COVID-19 by country of } \\
\text { birth }\end{array}$ & $\begin{array}{l}32 \% \text { of cases were immigrants, despite making up } \\
19 \% \text { of the population; highest incidence among } \\
\text { those born in Turkey, Ethiopia, and Somalia }\end{array}$ & $\mathrm{N} / \mathrm{A}$ \\
\hline $\begin{array}{l}\text { Statens Serum Institut } \\
\text { (Statens Serum } \\
\text { Institut 2020) }\end{array}$ & Denmark & $\begin{array}{l}\text { Migrants } \\
\text { and their } \\
\text { children }\end{array}$ & $\begin{array}{l}\text { Population- } \\
\text { based case } \\
\text { data }\end{array}$ & $\begin{array}{l}\text { National } \\
\text { statistics }\end{array}$ & $\begin{array}{l}29 \text { April to } 6 \\
\text { May }\end{array}$ & - & $\begin{array}{l}\text { Case, testing and incidence data, } \\
\text { comparing migrants and their } \\
\text { descendants with non-migrants }\end{array}$ & $\begin{array}{l}\text { Non-Western migrants and their native-born } \\
\text { children accounted for } 18 \% \text { of cases, despite making } \\
\text { up } 9 \% \text { of the population }\end{array}$ & $\mathrm{N} / \mathrm{A}$ \\
\hline $\begin{array}{l}\text { Statens Serum Institut } \\
\text { (Statens Serum } \\
\text { Institut 2020) }\end{array}$ & Denmark & $\begin{array}{l}\text { Migrants } \\
\text { and their } \\
\text { children }\end{array}$ & $\begin{array}{l}\text { Population- } \\
\text { based data } \\
\text { on cases, } \\
\text { hospitalisa- } \\
\text { tion and } \\
\text { mortality }\end{array}$ & $\begin{array}{l}\text { National } \\
\text { statistics }\end{array}$ & $\begin{array}{l}29 \text { April to } 7 \\
\text { September }\end{array}$ & - & $\begin{array}{l}\text { Case, testing incidence, hospitalisation } \\
\text { and mortality data, comparing } \\
\text { migrants and their descendants with } \\
\text { non-migrants }\end{array}$ & $\begin{array}{l}\text { Non-Western migrants and their native-born } \\
\text { children accounted for } 26 \% \text { of cases, and } 15 \% \text { of } \\
\text { COVID- } 19 \text { hospital admissions, despite making up } 9 \% \\
\text { of the population }\end{array}$ & $\mathrm{N} / \mathrm{A}$ \\
\hline $\begin{array}{l}\text { Guijarro } \\
\text { (Guijarro et al., 2020) }\end{array}$ & $\begin{array}{l}\text { Alcorcón, } \\
\text { Spain }\end{array}$ & Migrants & $\begin{array}{l}\text { Population- } \\
\text { based cohort } \\
\text { study }\end{array}$ & Pre-print & $\begin{array}{l}1 \text { February to } \\
25 \text { April }\end{array}$ & $\begin{array}{l}152,018 \\
\text { residents }\end{array}$ & $\begin{array}{l}\text { Incidence of COVID-19 in migrants } \\
\text { versus Spaniards and relative risk by } \\
\text { region of origin }\end{array}$ & $\begin{array}{l}\text { Crude incidence of COVID- } 19 \text { among migrants was } \\
\text { higher than among Spaniards, at } 8.71 \text { and } 6.51 \text { per } \\
1000 \text { inhabitants respectively }(\mathrm{p}<0.001)\end{array}$ & $8 / 8(100)$ \\
\hline $\begin{array}{l}\text { Grilli (Grilli et al., } \\
\text { 2020) }\end{array}$ & $\begin{array}{l}\text { Reggio } \\
\text { Emilia, Italy }\end{array}$ & Migrants & $\begin{array}{l}\text { Population- } \\
\text { based case } \\
\text { data }\end{array}$ & $\begin{array}{l}\text { Peer- } \\
\text { reviewed } \\
\text { publication }\end{array}$ & $\begin{array}{l}6 \text { March to } 26 \\
\text { March }\end{array}$ & 2635 tested & $\begin{array}{l}\text { Odds of COVID-19 infection and being } \\
\text { tested in migrants versus Italians }\end{array}$ & $\begin{array}{l}\text { Immigrants and Italians had a similar prevalence of } \\
\text { infection (OR } 0.99,95 \% \mathrm{CI} 0.82-1.20 \text { ) and similar } \\
\text { probability of being tested (OR } 0.93,95 \% \mathrm{CI} \\
0.81-1.10 \text { ) }\end{array}$ & $\mathrm{N} / \mathrm{A}$ \\
\hline $\begin{array}{l}\text { Strully (Strully et al., } \\
\text { 2020) }\end{array}$ & USA & Migrants & $\begin{array}{l}\text { Spatial } \\
\text { comparison }\end{array}$ & $\begin{array}{l}\text { Peer- } \\
\text { reviewed } \\
\text { publication }\end{array}$ & To 28 May & - & $\begin{array}{l}\text { Association of proportion of migrants } \\
\text { living in a region with COVID-19 case } \\
\text { rates }\end{array}$ & $\begin{array}{l}\text { Percentage of foreign-born residents was positively } \\
\text { associated with COVID-19 case rate (fully adjusted } \\
\text { IRR }=1.106,95 \% \text { CI } 1.074-1.139, \mathrm{p}<0.01 \text { ) at county } \\
\text { level }\end{array}$ & $8 / 8(100)$ \\
\hline
\end{tabular}




\begin{tabular}{|c|c|c|c|c|c|c|c|c|c|}
\hline Authors* & Location & Population & Study design & $\begin{array}{l}\text { Publication } \\
\text { type }\end{array}$ & Study period & Sample size & Methods & Key results & $\begin{array}{l}\text { Quality } \\
\text { appraisal } \\
\text { score (\%) }\end{array}$ \\
\hline $\begin{array}{l}\text { Jaqueti Aroca } \\
\text { (Jaqueti Aroca et al., } \\
\text { 2020) }\end{array}$ & $\begin{array}{l}\text { Madrid, } \\
\text { Spain }\end{array}$ & Migrants & $\begin{array}{l}\text { Case/testing } \\
\text { data }\end{array}$ & $\begin{array}{l}\text { Peer- } \\
\text { reviewed } \\
\text { publication }\end{array}$ & $\begin{array}{l}\text { To the second } \\
\text { week of April }\end{array}$ & $\begin{array}{l}1,781 \\
\text { patients }\end{array}$ & $\begin{array}{l}\text { Percentage positivity among } \\
\text { foreign-born versus Spaniards in } \\
\text { hospitals }\end{array}$ & $\begin{array}{l}\text { No significant difference in percentage positivity } \\
\text { between migrants and Spaniards (OR } 1.08,95 \% \mathrm{CI} \\
0.95-1.24 \text { ), but those from Latin America are at } \\
\text { higher risk; only } 12.5 \% \text { of positive migrants were } \\
>65 \text { years versus } 56.9 \% \text { Spaniards }\end{array}$ & $8 / 10(80)$ \\
\hline $\begin{array}{l}\text { Chew (Chew et al., } \\
\text { 2020) }\end{array}$ & Singapore & $\begin{array}{l}\text { Migrant } \\
\text { workers }\end{array}$ & $\begin{array}{l}\text { Case/testing } \\
\text { data and } \\
\text { clinical } \\
\text { evaluation }\end{array}$ & $\begin{array}{l}\text { Peer- } \\
\text { reviewed } \\
\text { publication }\end{array}$ & 11 to 19 April & $\begin{array}{l}5,977 \\
\text { migrant } \\
\text { workers }\end{array}$ & $\begin{array}{l}\text { Review of data from an outbreak } \\
\text { investigation among migrant workers } \\
\text { in a dormitory, including test } \\
\text { positivity and clinical parameters }\end{array}$ & $\begin{array}{l}1832 \text { of } 5977 \text { migrant workers were symptomatic, of } \\
\text { which } 1264(69 \%) \text { were positive for COVID-19, } \\
\text { corresponding to } 21 \% \text { of the cohort }\end{array}$ & $6 / 10(60)$ \\
\hline $\begin{array}{l}\text { Alkhamis } \\
\text { (Alkhamis et al., 2020) }\end{array}$ & Kuwait & $\begin{array}{l}\text { Migrant } \\
\text { workers }\end{array}$ & $\begin{array}{l}\text { Population- } \\
\text { based case } \\
\text { data }\end{array}$ & $\begin{array}{l}\text { Peer- } \\
\text { reviewed } \\
\text { journal }\end{array}$ & $\begin{array}{l}23 \text { February to } \\
7 \text { May }\end{array}$ & 5988 cases & $\begin{array}{l}\text { Modelling pandemic progression } \\
\text { (spatiotemporal cluster analysis) in } \\
\text { Kuwait citizens/ residents and migrant } \\
\text { workers }\end{array}$ & $\begin{array}{l}78.8 \% \text { of COVID- } 19 \text { cases were in migrant workers, } \\
40.1 \% \text { of which were of Indian nationality; } \\
\text { significant spreading events among migrant workers }\end{array}$ & $6 / 10(60)$ \\
\hline $\begin{array}{l}\text { Openshaw } \\
\text { (Openshaw and } \\
\text { Travassos, 2020) }\end{array}$ & USA & $\begin{array}{l}\text { Migrants in } \\
\text { detention } \\
\text { centres }\end{array}$ & $\begin{array}{l}\text { Viewpoint } \\
\text { (in }\end{array}$ & $\begin{array}{l}\text { Peer- } \\
\text { reviewed } \\
\text { publication }\end{array}$ & To May & - & $\begin{array}{l}\text { Reports COVID-19 cases at ICE } \\
\text { detention centres }\end{array}$ & $\begin{array}{l}\text { Over } 1200 \text { confirmed COVID- } 19 \text { cases across } 52 \\
\text { facilities run by ICE }\end{array}$ & $6 / 6(100)$ \\
\hline $\begin{array}{l}\text { ECDC } \\
\text { (European Centre for } \\
\text { Disease Prevention } \\
\text { and Control 2020) }\end{array}$ & $\begin{array}{l}\mathrm{EU} / \mathrm{EEA} \text { and } \\
\mathrm{UK}\end{array}$ & $\begin{array}{l}\text { Migrants in } \\
\text { detention } \\
\text { centres }\end{array}$ & $\begin{array}{l}\text { Report } \\
\text { reporting } \\
\text { cases }\end{array}$ & Grey & To June & - & $\begin{array}{l}\text { Reports COVID-19 cases at detention } \\
\text { centres in Europe }\end{array}$ & $\begin{array}{l}\text { Reported outbreaks in detention centres in Germany } \\
\text { and Portugal }\end{array}$ & $6 / 6(100)$ \\
\hline $\begin{array}{l}\text { Ministry of Health } \\
\text { (Ministry of Health } \\
\text { Singapore 2020) }\end{array}$ & Singapore & $\begin{array}{l}\text { Migrant } \\
\text { workers }\end{array}$ & $\begin{array}{l}\text { Population- } \\
\text { based case } \\
\text { data }\end{array}$ & $\begin{array}{l}\text { National } \\
\text { statistics }\end{array}$ & $18 \mathrm{Nov}$ & $\begin{array}{l}5,704,000 \\
\text { (population) }\end{array}$ & $\begin{array}{l}\text { Surveillance of new confirmed cases } \\
\text { in the past } 14 \text { days, including } \\
\text { proportion in dorm residents }\end{array}$ & $\begin{array}{l}54,502(95.7 \%) \text { of } 58,135 \text { all in-country cases of } \\
\text { COVID- } 19 \text { were in migrants residing in dormitories }\end{array}$ & $2 / 10(20)$ \\
\hline $\begin{array}{l}\text { Ministry of Health } \\
\text { (Ministry of Health } \\
\text { Saudi Arabia } 7 \text { May } \\
\text { 2020) }\end{array}$ & Saudi Arabia & Migrants & $\begin{array}{l}\text { Population- } \\
\text { based case } \\
\text { data }\end{array}$ & $\begin{array}{l}\text { National } \\
\text { statistics }\end{array}$ & To 7 May & - & Routine surveillance & $\begin{array}{l}75 \% \text { of all people in-country who have tested } \\
\text { positive for COVID- } 19 \text { were migrants }\end{array}$ & $\mathrm{N} / \mathrm{A}$ \\
\hline $\begin{array}{l}\text { Greek Ministry of } \\
\text { Health } \\
\text { (Greek Ministry of } \\
\text { Health 2020) }\end{array}$ & Greece & $\begin{array}{l}\text { Migrants } \\
\text { and refugees }\end{array}$ & $\begin{array}{l}\text { Hospital- } \\
\text { based case } \\
\text { data }\end{array}$ & $\begin{array}{l}\text { National } \\
\text { statistics }\end{array}$ & $\begin{array}{l}\text { To } 16 \\
\text { September }\end{array}$ & - & Routine surveillance & $\begin{array}{l}\text { Almost half of COVID- } 19 \text { patients hospitalised in } \\
\text { Attica are refugees from camps/hosting sites or } \\
\text { destitute migrants }\end{array}$ & $\mathrm{N} / \mathrm{A}$ \\
\hline $\begin{array}{l}\text { Buda (Buda et al., } \\
\text { 2020) }\end{array}$ & Germany & Refugees & $\begin{array}{l}\text { Outbreaks } \\
\text { case data }\end{array}$ & $\begin{array}{l}\text { National } \\
\text { statistics }\end{array}$ & To 11 August & - & $\begin{array}{l}\text { Collation of outbreak reports, } \\
\text { assessing the proportion in refugee } \\
\text { centres (vs other settings such as } \\
\text { nursing homes) }\end{array}$ & $\begin{array}{l}2.5 \% \text { of notified outbreaks ( } 199 \text { of } 7864) \text { were } \\
\text { reported in refugee centres, comprising } 7.5 \% \\
(n=4,146) \text { of all notified cases during outbreaks } \\
(n=55,141)\end{array}$ & $\mathrm{N} / \mathrm{A}$ \\
\hline $\begin{array}{l}\text { Bozorgmehr } \\
\text { (Bozorgmehr et al., } \\
\text { 2020) }\end{array}$ & Germany & $\begin{array}{l}\text { Refugees in } \\
\text { reception/ } \\
\text { accommoda- } \\
\text { tion } \\
\text { centres }\end{array}$ & $\begin{array}{l}\text { Outbreaks } \\
\text { case data }\end{array}$ & Grey & To 22 May & $\begin{array}{l}9785 \\
\text { refugees }\end{array}$ & $\begin{array}{l}\text { Meta-analysis of media reports in } \\
\text { Germany to identify } \\
\text { pooled cumulative incidence rate in } \\
\text { refugee reception/ accommodation } \\
\text { centres }\end{array}$ & $\begin{array}{l}\text { Identified } 42 \text { outbreaks in } 11 \text { federal states, with } \\
1769 \text { confirmed cases; IR of } 17.0 \% \text { ( } 95 \% \text { CI } 12.0 \text { to } \\
23.0, \mathrm{I}^{2}=98.3 \% \text { ) }\end{array}$ & $\mathrm{N} / \mathrm{A}$ \\
\hline \multicolumn{10}{|c|}{ COVID-19 hospitalisation } \\
\hline $\begin{array}{l}\text { Giorgi Rossi } \\
\text { (Giorgi Rossi et al., } \\
\text { 2020) }\end{array}$ & $\begin{array}{l}\text { Reggio } \\
\text { Emilia, Italy }\end{array}$ & Migrants & $\begin{array}{l}\text { Population- } \\
\text { based cohort } \\
\text { study }\end{array}$ & $\begin{array}{l}\text { Peer- } \\
\text { reviewed } \\
\text { publication }\end{array}$ & $\begin{array}{l}27 \text { February to } \\
2 \text { April }\end{array}$ & 2,653 tested & $\begin{array}{l}\text { COVID-19 incidence, hospitalisation } \\
\text { and death in migrants versus Italians }\end{array}$ & $\begin{array}{l}\text { Immigrants had a higher risk of hospitalisation (HR } \\
1.3,95 \% \mathrm{CI} 0.99-1.81 \text { ) than Italians }\end{array}$ & $7 / 10(70)$ \\
\hline $\begin{array}{l}\text { Hamadah (Hamadah H } \\
\text { and Behbehani, 2020) }\end{array}$ & Kuwait & Migrants & $\begin{array}{l}\text { Hospital- } \\
\text { based cohort } \\
\text { study }\end{array}$ & $\begin{array}{l}\text { Peer- } \\
\text { reviewed } \\
\text { publication }\end{array}$ & $\begin{array}{l}24 \text { February to } \\
20 \text { April }\end{array}$ & $\begin{array}{l}1,123 \\
\text { patients }\end{array}$ & $\begin{array}{l}\text { Comparison of ICU admission, ARDS, } \\
\text { pneumonia and mortality in migrants } \\
\text { and non-migrants }\end{array}$ & $\begin{array}{l}\text { Migrants had increased odds of death or ICU } \\
\text { admission (OR 2.14, 95\% CI 1.12-4.32), ARDS (OR } \\
2.44,95 \% \text { CI 1.23-5.09) and pneumonia (OR 2.24, 95\% } \\
\text { CI 1.27-4.12) }\end{array}$ & $8 / 8(100)$ \\
\hline $\begin{array}{l}\text { Fabiani (Fabiani et al., } \\
\text { 2020) }\end{array}$ & Italy & Migrants & $\begin{array}{l}\text { Population- } \\
\text { based } \\
\text { clinical and } \\
\text { mortality } \\
\text { data }\end{array}$ & Pre-print & $\begin{array}{l}20 \text { Feb to } 19 \\
\text { July }\end{array}$ & $\begin{array}{l}213,180 \\
\text { cases }\end{array}$ & $\begin{array}{l}\text { Comparison of case fatality rate and } \\
\text { rate of admission to hospital and ICU } \\
\text { between migrants versus Italians }\end{array}$ & $\begin{array}{l}\text { Non-Italian cases were diagnosed at a later date } \\
\text { than Italian cases and were more likely to be } \\
\text { hospitalised (ARR=1.39, } 95 \% \text { CI } 1.33-1.44 \text { ) and } \\
\text { admitted to an ICU (ARR=1.19, } 95 \% \text { CI 1.07-1.32) }\end{array}$ & $8 / 8(100)$ \\
\hline
\end{tabular}




\begin{tabular}{|c|c|c|c|c|c|c|c|c|c|}
\hline Authors* & Location & Population & Study design & $\begin{array}{l}\text { Publication } \\
\text { type }\end{array}$ & Study period & Sample size & Methods & Key results & $\begin{array}{l}\text { Quality } \\
\text { appraisal } \\
\text { score (\%) }\end{array}$ \\
\hline \multicolumn{10}{|l|}{ COVID-19 mortality } \\
\hline $\begin{array}{l}\text { Canevelli } \\
\text { (Canevelli et al., 2020) }\end{array}$ & Italy & Migrants & $\begin{array}{l}\text { Temporal } \\
\text { comparison }\end{array}$ & $\begin{array}{l}\text { Peer- } \\
\text { reviewed } \\
\text { publication }\end{array}$ & $\begin{array}{l}21 \text { February to } \\
29 \text { April }\end{array}$ & $\begin{array}{l}2,687 \\
\text { deceased } \\
\text { cases }\end{array}$ & $\begin{array}{l}\text { Comparison of proportion of migrants } \\
\text { in COVID-19 deaths versus all-cause } \\
\text { mortality in } 2018\end{array}$ & $\begin{array}{l}\text { The proportion of migrants and non-migrants among } \\
\text { COVID-related deaths ( } 2.5 \% \text { and } 97.5 \% \text { respectively) } \\
\text { was similar to the estimated } 2018 \text { all-cause } \\
\text { mortality rates ( } 2.6 \% \text { and } 97.4 \% \text { ); but migrants were } \\
\text { younger at the time of death versus non-migrants } \\
\text { ( } 71.1, \text { SD } 13.1 \text { vs } 78.3, \text { SD } 10.8, p<0.001 \text { ) }\end{array}$ & $9 / 10(90)$ \\
\hline $\begin{array}{l}\text { Public Health England } \\
\text { (Public Health } \\
\text { England 2020) }\end{array}$ & England & Migrants & $\begin{array}{l}\text { Temporal } \\
\text { comparison }\end{array}$ & Grey & $\begin{array}{l}21 \text { March to } 8 \\
\text { May }\end{array}$ & - & $\begin{array}{l}\text { Comparison of all-cause mortality in } \\
2020 \text { versus 2014-2018 in migrants } \\
\text { and UK-born }\end{array}$ & $\begin{array}{l}\text { Deaths in } 2020 \text { were over } 3 \text { times higher than } \\
2014-2018 \text { for those from Central and Western } \\
\text { Africa, the Caribbean, South East Asia, Middle East, } \\
\text { and South and Eastern Africa, versus } 1.7 \text { times } \\
\text { higher overall in England }\end{array}$ & $8 / 8(100)$ \\
\hline $\begin{array}{l}\text { Papon (Papon and } \\
\text { Robert-Bobée, 2020) }\end{array}$ & France & Migrants & $\begin{array}{l}\text { Temporal } \\
\text { comparison }\end{array}$ & Grey & March to April & - & $\begin{array}{l}\text { Comparison of proportion of migrants } \\
\text { in registered deaths in } 2020 \text { versus } \\
2014-2019\end{array}$ & $\begin{array}{l}\text { The foreign-born represented } 15 \% \text { of registered } \\
\text { deaths in March and April } 2020 \text { versus } 13 \% \text { in March } \\
\text { and April } 2019\end{array}$ & $6 / 10(60)$ \\
\hline $\begin{array}{l}\text { Observatoire Regional } \\
\text { de Sante Ile de France } \\
\text { (Observatoire Regional } \\
\text { de Sante Ile de France } \\
\text { 2020) }\end{array}$ & Paris, France & Migrants & $\begin{array}{l}\text { Spatial } \\
\text { comparison }\end{array}$ & Grey & March 2020 & Not stated & $\begin{array}{l}\text { Mortality (daily deaths) by Parisian } \\
\text { departments (areas) compared with } \\
\text { sociodemographic characteristics of } \\
\text { the department. }\end{array}$ & $\begin{array}{l}\text { Eg. Seine-Saint-Denis, a district in the north of Paris } \\
\text { where } 30 \% \text { of the population is an immigrant, had a } \\
188 \% \text { mortality increase compared with } 2019 \text { versus } \\
\text { a } 96 \% \text { increase in Paris as a whole }\end{array}$ & $1 / 10(10)$ \\
\hline $\begin{array}{l}\text { Kunst (Kunst et al., } \\
\text { 2020) }\end{array}$ & Netherlands & $\begin{array}{l}\text { Migrants } \\
\text { and their } \\
\text { children }\end{array}$ & $\begin{array}{l}\text { Temporal } \\
\text { comparison }\end{array}$ & $\begin{array}{l}\text { National } \\
\text { statistics }\end{array}$ & March to April & - & $\begin{array}{l}\text { Comparison of mortality in } \\
\text { March-April versus in the preceding } \\
\text { weeks, adjusted for seasonal factors, } \\
\text { in migrants versus Dutch }\end{array}$ & $\begin{array}{l}\text { Mortality was } 47 \% \text { higher than expected for } \\
\text { immigrants from non-Western countries and their } \\
\text { children, } 49 \% \text { higher for immigrants from Western } \\
\text { countries and their children, and } 38 \% \text { higher for the } \\
\text { native-born with Dutch parents }\end{array}$ & $\mathrm{N} / \mathrm{A}$ \\
\hline $\begin{array}{l}\text { Hansson } \\
\text { (Hansson et al., 2020) }\end{array}$ & Sweden & Migrants & $\begin{array}{l}\text { Temporal } \\
\text { comparison }\end{array}$ & $\begin{array}{l}\text { Peer- } \\
\text { reviewed } \\
\text { publication }\end{array}$ & $\begin{array}{l}\text { February to } \\
\text { May }\end{array}$ & - & $\begin{array}{l}\text { Comparison of all-cause mortality in } \\
2020 \text { versus } 2016-2019 \text { by region of } \\
\text { birth }\end{array}$ & $\begin{array}{l}\text { Among middle-aged ( } 40-64 \text { years) and older ( }>65 \\
\text { years) people born in Syria, Iraq and Somalia excess } \\
\text { mortality was } \sim 220 \% \text {; among those born in Sweden, } \\
\text { the EU, the Nordic countries or North America, } \\
\text { excess mortality among those }>65 \text { was } 19 \% \text { and } \\
\text { among the middle aged was } 1 \%\end{array}$ & $\mathrm{~N} / \mathrm{A}$ \\
\hline $\begin{array}{l}\text { Calderón-Larrañaga } \\
\text { (Calderón- } \\
\text { Larrañaga et al., } \\
\text { 2020) }\end{array}$ & $\begin{array}{l}\text { Stockholm, } \\
\text { Sweden }\end{array}$ & Migrants & $\begin{array}{l}\text { Spatial/ } \\
\text { temporal } \\
\text { comparison }\end{array}$ & $\begin{array}{l}\text { Peer- } \\
\text { reviewed } \\
\text { publication }\end{array}$ & 6-12 April & $\begin{array}{l}2,379,792 \\
\text { residents }\end{array}$ & $\begin{array}{l}\text { Comparison of excess mortality } \\
\text { compared with previous } 5 \text { years in } \\
\text { areas according to share of migrants }\end{array}$ & $\begin{array}{l}\text { Areas with the lowest tercile share of Swedish-born } \\
\text { had } 178 \% \text { excess mortality compared with the } \\
\text { previous } 5 \text { years }\end{array}$ & $6 / 10(60)$ \\
\hline $\begin{array}{l}\text { Drefahl (Drefahl et al., } \\
\text { 2020) }\end{array}$ & Sweden & Migrants & $\begin{array}{l}\text { Individual- } \\
\text { level } \\
\text { survival } \\
\text { analysis }\end{array}$ & $\begin{array}{l}\text { Peer- } \\
\text { reviewed } \\
\text { publication }\end{array}$ & To 7 May & $\begin{array}{l}1,189,484 \text { py } \\
(17,181 \\
\text { deaths })\end{array}$ & $\begin{array}{l}\text { Risk of death from COVID-19 in } \\
\text { individual-level data according to } \\
\text { migrant status and region of origin }\end{array}$ & $\begin{array}{l}\text { Immigrants from LMICs from the Middle East and } \\
\text { North Africa showed increased mortality among men } \\
\text { (HR 3.13, } 95 \% \mathrm{CI} 2.51-3.90 \text { ) and women (HR 2.09, } \\
95 \% \text { CI 1.52-2.89) as compared to the Swedish-born }\end{array}$ & $8 / 10(80)$ \\
\hline $\begin{array}{l}\text { Rostila (Rostila et al., } \\
\text { 2020) }\end{array}$ & $\begin{array}{l}\text { Stockholm, } \\
\text { Sweden }\end{array}$ & Migrants & $\begin{array}{l}\text { Population- } \\
\text { based cohort } \\
\text { study }\end{array}$ & Grey & 31 Jan to 4 May & $\begin{array}{l}1,778,670 \\
\text { individuals }\end{array}$ & $\begin{array}{l}\text { Risk of death from COVID-19 in } \\
\text { individual-level data according to } \\
\text { migrant status and region of origin }\end{array}$ & $\begin{array}{l}\text { Migrants from Middle Eastern countries (RR 3.2, 95\% } \\
\text { CI 2.6-3.8), Africa (RR 3.0, 95\% CI 2.2-4.3) and the } \\
\text { Nordic countries (RR 1.5, 95\% CI 1.2-1.8) had higher } \\
\text { COVID-19 mortality versus the Swedish-born }\end{array}$ & $9 / 11(82)$ \\
\hline $\begin{array}{l}\text { Centrum for } \\
\text { epidemiologi och } \\
\text { samhallsmediccin } \\
\text { (Centrum for } \\
\text { epidemiologi och } \\
\text { samhallsmediccin RS } \\
\text { 2020) }\end{array}$ & $\begin{array}{l}\text { Stockholm, } \\
\text { Sweden }\end{array}$ & Migrants & $\begin{array}{l}\text { Individual- } \\
\text { level } \\
\text { survival } \\
\text { analysis }\end{array}$ & Grey & To 30 June & - & $\begin{array}{l}\text { Risk of death from COVID-19 in } \\
\text { individual-level data according to } \\
\text { country of birth, among those aged } 25 \\
\text { years and older }\end{array}$ & $\begin{array}{l}\text { Migrants from Somalia (HR 12.39, 95\% CI } \\
\text { 7.93-19.36), Lebanon (HR 6.19, 95\% CI 3.41-11.24), } \\
\text { and Syria (HR 6.14, 95\% CI 4.28-8.80) show } \\
\text { increased risk of death compared with } \\
\text { Swedish-born, adjusted for age and sex }\end{array}$ & $\mathrm{N} / \mathrm{A}$ \\
\hline $\begin{array}{l}\text { Cook (Cook et al., } \\
\text { 2020) }\end{array}$ & UK & $\begin{array}{l}\text { Migrant } \\
\text { healthcare } \\
\text { workers } \\
\text { (HCWs) }\end{array}$ & $\begin{array}{l}\text { Characterisatio } \\
\text { of reported } \\
\text { HCW deaths }\end{array}$ & $\begin{array}{l}\text { Grey } \\
\text { on }\end{array}$ & To 22 April & 106 HCWs & $\begin{array}{l}\text { Proportion of UK healthcare workers } \\
\text { who died who were born outside the } \\
\text { UK }\end{array}$ & $\begin{array}{l}\text { Of } 106 \text { UK healthcare workers who died up until } 22 \\
\text { April } 2020 \text {, at least } 56 \text { (53\%) were born outside the } \\
\text { UK }\end{array}$ & $4 / 10(40)$ \\
\hline
\end{tabular}

${ }^{*}$ Where papers report on multiple outcomes (cases, hospitalisations, deaths) papers are included under the first relevant sub-heading only 
confirmed SARS-CoV2 cases among 9785 refugees in those centres. The pooled cumulative incidence rate (attack rate) was reported as $17.0 \%$ (95\% CI 12.0-23.0, I2 = 98.3\%) (Bozorgmehr et al., 2020).

A temporal and spatiotemporal dynamics study of the COVID-19 pandemic in Kuwait using daily confirmed case data collected between the 23 February and 7 May concluded that densely populated areas and poor living conditions of migrant workers resulted in the highest number of significant spreading and clustering events within their communities (Alkhamis and Khajah, 2020).

We found one Italian study reporting no differences between migrants and non-migrants in terms of the probability of being tested (OR 0.93 ; $95 \%$ CI $0.81-1.1$ ) and a similar prevalence of infection (OR 0.99; 95\% CI 0.82-1.20) (Grilli et al., 2020).

\subsubsection{Hospitalisation due to COVID-19}

In a prospective COVID-19 registry study $(n=1123)$ comparing Kuwaitis with non-Kuwaitis/migrants (two-thirds of the Kuwaiti population are migrants, the majority of non-Kuwaitis are migrant workers) in the main COVID-19-specific healthcare facility in the country, with adjustments made to age, gender, smoking and selected co-morbidities, non-Kuwaitis ( $91.6 \%$ males; mean age 41.0 years) had two-fold increase in the odds of death or being admitted to the intensive care unit compared to Kuwaitis (OR 2.14, 95\% CI 1.12-4.32). Non-Kuwaitis also had higher odds of acute respiratory distress syndrome [ARDS] (OR $2.44,95 \%$ CI 1.23-5.09) and pneumonia (OR 2.24, 95\% CI 1.27-4.12) (Hamadah and Behbehani, 2020).

In Denmark, non-Western migrants and their children accounted for 15\% of COVID-19 hospital admissions (to 7 September), despite only making up 9\% of the population Statens Serum Institut (2020).

In one province in Italy (27 February to 2 April), migrants were found to have a higher risk of hospitalisation (hazard ratio [HR] 1.3, 95\% CI 0.99-1.81) than Italians (Giorgi Rossi et al., 2020). In Italian surveillance data (to 19 July) non-Italian cases were diagnosed at a later date than Italian cases and were more likely to be hospitalised (adjusted relative risk 1.39 [95\% CI 1.33-1.44]) and admitted to an intensive care unit (1.19 [95\% CI 1.07-1.32]), especially in those coming from lower human development index countries (Fabiani et al., 2020).

In Greece, almost half of COVID-19 patients hospitalised in Attica (Athens and surrounding areas) as of 17 Sept were refugees from camps/hosting sites and destitute migrants from the city centre, including in Sotiria hospital (40 of 103 are refugees), Evaggelismos (36 of 66), Amalia Fleming (10 of 20) and Attikon (26 of 26); many of these patients were reported to be "asymptomatic and young" but could not be returned to overcrowded accommodation (Greek Ministry of Health 2020).

\subsubsection{COVID-19 mortality and excess deaths}

An analysis of all recorded COVID-19 deaths (to 7 May) in Sweden found that being an migrant from an LMIC is predictive of a higher risk of death from COVID-19, but not for all other causes of death (Drefahl et al., 2020). In models adjusting for age and sociodemographics, migrants from LMICs from the Middle East and North Africa had a three times higher mortality rate from COVID-19 among men (HR 3.13, 95\% CI 2.51-3.90) and two times higher mortality among women (HR 2.09, 95\% CI 1.52-2.89) as compared to the Swedish-born (Drefahl et al., 2020). Similarly, data from Stockholm, Sweden until 4 May shows that migrants from Middle Eastern countries (RR 3.2, 95\% CI 2.6-3.8), Africa (RR 3.0, 95\% CI 2.2-4.3) and the Nordic countries (RR 1.5, 95\% CI 1.2-1.8) had higher COVID-19 mortality when compared to Swedish-born people, adjusting for age, sex and sociodemographic characteristics. Especially high mortality risks from COVID-19 were found among individuals born in Somalia (RR 8.9, 95\% CI 5.614.0), Lebanon (RR 5.9, 95\% CI 3.4-10.3) and Syria (RR 4.7, 95\% CI 3.3-6.6) (Rostila et al., 2020).

An epidemiological report that compared risk of death from COVID19 in over 25-year olds who were foreign-born versus Swedish-born of the same age to 30 June in Stockholm Country found marked differences between Swedish-born and Somali (HR adjusted for age and sex 12.39 [7.93-19.36]), Lebanese (6.19 [3.41-11.24]), and Syrian (6.14 [4.28-8.80]) migrants (Hansson et al., 2020). These effects were attenuated when adjusted for neighbourhood, education level, occupation, income, household size and previous chronic illness, but remained higher among migrants than Swedish-born (Centrum for epidemiologi och samhallsmediccin RS 2020). In a brief report of 106 healthcare workers who died in the UK up until 22 April 2020, 56 (53\%) were reportedly born outside the UK (Cook et al., 2020).

No differences in mortality from COVID-19 by migration status were observed in crude analyses by migrant status in Denmark (data to 7 September) (Statens Serum Institut 2020). In one province of Italy, migrants were found to have a similar risk of death to non-migrants (27 February to 2 April) (Giorgi Rossi et al., 2020). However, Italian surveillance data from the start of the outbreak to 19 July found an increased risk of death in non-Italians from low-Human Development Index countries (adjusted RR 1.32, 95\% CI 1.01-1.75) (Fabiani et al., 2020).

Definitional and data collection challenges mean that attention has focused on all cause excess mortality during the pandemic, comparing deaths with those expected on the basis of rates in preceding years. In England, for example (21 March to 8 May) where the number of death registrations from all causes was 1.7 times higher than the average during the same period in 2014-2018, the relative increase in total deaths was greater among those born outside the UK; deaths in 2020 were over 3 times higher than the equivalent period in 2014 to 2018 for those from Central and Western Africa (4.5 times higher) the Caribbean (3.5), South East Asia (3.4), Middle East (3.2) and South and Eastern Africa (3.1). For migrants born in other countries within the EU (internal migrants) the level of increased risk was similar to those born in the UK (Public Health England, 2020).

In France, foreign-born people represented $15 \%$ of registered deaths (March and April 2020) versus 13\% for the same period in 2019. This includes an increase of 54\% deaths among migrants from North Africa (Algeria, Morocco, Tunisia), 114\% for those from sub-Saharan Africa, and 91\% for those from Asia. Migrants from other parts of Europe, America or Oceania had similar mortality rates to the French-born, who experienced a 22\% excess mortality (Papon and Robert-Bobée, 2020). This same trend is also seen in different regions of France; for example SeineSaint-Denis, a district in the north of Paris where $30 \%$ of the population are immigrants, saw a $188 \%$ mortality increase compared with 2019 , versus a $96 \%$ increase in Paris as a whole (Observatoire Regional de Sante Ile de France 2020).

In the Netherlands (9 March to 19 April 2020), mortality was $47 \%$ higher than expected for migrants from non-Western countries and their immediate children (based on number of deaths in the preceding weeks, adjusted for seasonal factors), $49 \%$ higher for migrants from Western countries and their children, and 38\% higher for the native-born people with Dutch parents (Kunst et al., 2020).

In Sweden, mortality among migrants was elevated in 2020 compared with previous years. A comparison between all-cause mortality data from March to May 2020 with data from the same period in 2016 to 2019 found that among middle-aged (40-64 years) and older ( $>65$ years) migrants born in Syria, Iraq and Somalia excess mortality was approximately $220 \%$. Among people born in Sweden, the EU, the Nordic countries or North America, the excess mortality among those $>65$ was $19 \%$ and among the middle aged was $1 \%$ (Hansson et al., 2020). In Stockholm during the peak of the epidemic (6 to 12 April 2020), areas with the lowest tercile of share of Swedish-born had 178\% excess mortality compared with the previous five years (Calderón-Larrañaga et al., 2020).

In Italy, on the other hand, between 21 February and 29 April 2020, found the share of migrants and non-migrants among COVID-related deaths $(2.5 \%$ and $97.5 \%$ respectively) was similar to their share in allcause mortality rates estimated in Italy in 2018 (2.6\% and $97.4 \%$ respectively) (Canevelli et al., 2020). However, migrants were younger at 
the time of death than non-migrants (71.1, standard deviation [SD] 13.1 years vs 78.3, SD 10.8 years, $p<0.001)$.

\subsection{Indirect health and social impacts}

The mental health impact of the COVID-19 pandemic and associated restrictions has been well-documented. Migrants may be particularly affected due to pre-existing risk factors (Júnior et al., 2020, Falicov et al., 2020 ) and potential exclusion and social isolation (Doctors of the World 2020), and worsening of pre-existing mental health conditions (PinzónEspinosa et al., 2020, Endale et al., 2020); providing remote therapy for these individuals can be challenging (Mattar and Piwowarczyk, 2020). In one Canadian study, however, immigrants were found to be less likely to increase negative health behaviours than Canada-born adults (Zajacova et al., 2020). In a nationally representative US survey carried out in March 2020, COVID-19-related fear and associated anxiety and depressive symptoms were higher for migrants compared with the USborn $(p<0.001)$ (Fitzpatrick et al., 2020), with similar findings in other studies (Goodman et al., 2020, Choi et al., 2020). In a cross-sectional survey of 295 Filipino domestic helpers in Hong Kong, multivariate regression results showed that the insufficiency of personal protective equipment (PPE) (OR=1.58 [95\% CI 1.18-2.11]), increased workload (OR 1.51 [95\% CI 10.2-2.25]), and concerns about being forced out of their jobs if they test positive for COVID-19 (OR 1.32 [95\% CI 1.041.68]) were significantly associated with anxiety in a multivariate analysis (Yeung et al., 2020).

Migrants may be especially impacted by travel restrictions (Guadagno, 2020, Migration Data Portal 2020, Zajacova et al., 2020). Arriving migrants have been pushed back or quarantined at borders and forced to stay in informal or overcrowded transit sites, while international refugee resettlement programmes have been disrupted (Guadagno, 2020, Jauhiainen, 2020). For migrants who are already settled, but not considered resident, border restrictions may force them to overstay their visas, or prevent them from visiting family or friends outside of their host country, exacerbating feelings of isolation (Kanlungan Filipino Consortium 2020). Concerns have also been raised that border closures may increase smuggling of migrants (Sarrica et al., 2020). COVID-19 may meanwhile pose a barrier to integration for migrants and refugees (Falkenhain et al., 2020), for example due to the suspension and modification of resettlement schemes (Brickhill-Atkinson and Hauck, 2020, Rush, 2020), and education programmes (Brickhill-Atkinson and Hauck, 2020, Primdahl et al., 2020, Mupenzi et al., 2020, OECD 2020, Silverman et al., 2020). Migrants who are particularly vulnerable may be disproportionality affected by the negative social impact of lockdown (Zero and Geary, 2020, Sabri et al., 2020). Migrants are considered to be especially vulnerable to job loss and economic hardship as a result of COVID-19 (Kanlungan Filipino Consortium 2020, Brickhill-Atkinson and Hauck, 2020, OECD 2020, Wang et al., 2020, Dempster and Zimmer, 2020, Basso et al., 2020, Davis, 2020, Borjas and Cassidy, 2020, Pacheco et al., 2020, Garrote Sanchez et al., 2020). A qualitative cumulative risk assessment for migrant workers in Kuwait found many workers are now facing layoffs, furloughs, non-payment and late payment of wages putting them in significant financial hardship (Alahmad et al., 2020). Across Organisation for Economic Cooperation and Development (OECD) countries, approximately $30 \%$ of migrants are considered to be living in relative poverty, compared with $20 \%$ of the native-born people (OECD, 2020), which increases their vulnerability to COVID-19 infection (Doctors of the World 2020, Valeriani et al., 2020).

Migrants may also be experiencing discrimination as a result of the COVID-19 pandemic (Guadagno, 2020, Patel et al., 2020, Centre for British-Turkish Understanding 2020). In particular, Chinese and other Asian migrants have been targeted due to the original emergence of the pandemic in China, with reports of bullying, awkward behaviour, avoidance of Chinese restaurants and shops, and physical attacks (Bofulin, 2020, Cross and Benson, 2020, Aydemir and Akyol, 2020). In surveys and interviews with people of Chinese origin living in France, nearly a third reported having experienced at least one discriminatory act since January 2020 (Wang et al., 2020).

\subsection{Risk factors and vulnerabilities for COVID-19 in migrants}

Table 2 summarises key risk factors for migrants for COVID-19 reported from included data sources. Fig. 2 highlights key risk factors and vulnerabilities of migrants identified in the literature.

\subsubsection{Co-morbidities}

Co-morbidities may be a cause of increased COVID-19 risk and/or poor COVID-19 outcomes in migrant populations, but this remains poorly documented. A situational brief reporting on the health or asylum seekers and undocumented migrants in France during COVID-19 concludes they are more likely to have certain chronic conditions that appear to be associated with worse COVID-19 outcomes, such as diabetes mellitus, hypertension, and obesity (Gosselin et al., 2020). In Sweden, a COVID-19 situational report found around $65 \%$ of refugees are either overweight or obese compared to $50 \%$ in the rest of the population, and around 35\% are smokers, which is higher than the general population (Elisabeth et al., 2020). In addition, hospital visits for management of co-morbidities may increase risk of exposure to COVID-19 (Rizzolo et al., 2020). Co-infections may also play a role. In Lisbon, it has been observed that some of the neighbourhoods with increased transmission coincide with areas where TB incidence has been higher (Dias et al., 2020), with over half of patients with TB and COVID-19 in two early case series being migrants (Tadolini et al., 2020, Motta et al., 2020). Migrants in camp settings may be especially vulnerable due to existing illnesses or injuries and prevailing malnutrition and/or poor health in general (Iacobucci, 2020, Hargreaves et al., 2020, Jozaghi and Dahya, 2020, ACAPS 2020).

\subsubsection{Healthcare seeking and barriers to care}

Testing and treatment for COVID-19 has been made free of charge and exempt from immigration status checks in many countries, with these messages communicated in multiple languages; however, concerns remain that these exemptions do not fully mitigate the extensive barriers that migrants experience in accessing healthcare (Guadagno, 2020, Wood and Devakumar, 2020, Orcutt et al., 2020). Concerns within migrant communities that COVID-19 treatment might be chargeable, or that undocumented migrants might be identified by health systems on presentation remain, and could prevent early presentation and testing in migrants who distrust authorities (Doctors of the World, 2020, Kanlungan Filipino Consortium 2020, Germain and Yong, 2020). In the US, where nearly half of undocumented adult migrants and a quarter of lawfully present adult migrants lack health insurance (Cholera et al., 2020), or have insurance that relies on a specific employer, migrants may avoid seeking care for fear of losing their job and being deported (Doyle, 2020). Various federal policies deter migrants from health seeking (Page et al., 2020, Capps and Gelatt, 2020, Bakhiet et al. 2020, Zelaya et al. 2020). For example, undocumented migrants in the US are ineligible for federally funded healthcare programmes such as Medicare and Medicaid (Wilson et al., 2020), and the 'public charge' rule introduced in February 2020 makes migrants who receive a broad range of cash and noncash benefits ineligible to apply for citizenship and residency (Langellier, 2020, Behbahani et al., 2020), deterring treatmentseeking, particularly so in jobs that are often criminalised such as sex work (Lam, 2020). US Immigration and Customs Enforcement (ICE) raids have continued in migrant communities over lockdown, and have further damaged trust and deterred migrants from testing and treatment (Lopez and Holmes, 2020).

In an online survey of undocumented migrants (students who entered as minors) in the US (May 2020), 10\% said that they or an immediate family member suspected COVID-19 infection at some point but did not get tested for fear of detainment or deportation, and 1 in 5 
Table 2

Risk factors and vulnerabilities reported for migrants for COVID-19.

\begin{tabular}{|c|c|c|c|c|c|c|c|}
\hline \multirow[t]{2}{*}{ Authors } & \multirow[t]{2}{*}{ Location } & \multirow[t]{2}{*}{ Population } & \multicolumn{5}{|l|}{ Risk factors } \\
\hline & & & $\begin{array}{l}\text { Co- } \\
\text { morbidities }\end{array}$ & $\begin{array}{l}\text { Health } \\
\text { seeking and } \\
\text { health care }\end{array}$ & $\begin{array}{l}\text { Social and } \\
\text { cultural }\end{array}$ & Occupation & Details \\
\hline $\begin{array}{l}\text { Migration Data Portal } \\
\text { (Migration Data Portal 2020) }\end{array}$ & Global & Migrants & & & & $\mathrm{x}$ & Occupational risk (frontline/essential, HCWs) \\
\hline Júnior (Júnior et al., 2020) & Global & Refugees & & $\mathrm{x}$ & $\mathrm{x}$ & & $\begin{array}{l}\text { Conditions in camps (overcrowding, sanitation, healthcare, } \\
\text { language/culture) }\end{array}$ \\
\hline DotW (Doctors of the World 2020) & England & $\begin{array}{l}\text { Refugees, asylum } \\
\text { seekers, } \\
\text { undocumented } \\
\text { migrants }\end{array}$ & $\mathrm{x}$ & $\mathrm{x}$ & $\mathrm{x}$ & $\mathrm{x}$ & Socio-economic determinants; barriers to healthcare \\
\hline Valeriani (Valeriani et al., 2020) & Sweden & Migrants & $\mathrm{x}$ & $\mathrm{x}$ & $\mathrm{x}$ & $\mathrm{x}$ & $\begin{array}{l}\text { Socio-economic determinants; occupational risk (frontline); } \\
\text { barriers to healthcare }\end{array}$ \\
\hline $\begin{array}{l}\text { Brickhill-Atkinson } \\
\text { (Brickhill-Atkinson and } \\
\text { Hauck, 2020) }\end{array}$ & Global & Refugees & $\mathrm{x}$ & $\mathrm{x}$ & $\mathrm{x}$ & $\mathrm{x}$ & $\begin{array}{l}\text { Overcrowding; comorbidities; occupational risk (frontline); } \\
\text { barriers to healthcare (language, technological) }\end{array}$ \\
\hline Page (Page et al., 2020) & USA & $\begin{array}{l}\text { Undocumented } \\
\text { migrants }\end{array}$ & & $\mathrm{x}$ & & & Barriers to healthcare (immigration status, cultural, language) \\
\hline Langellier (Langellier, 2020) & USA & Non-citizens & & $\mathrm{x}$ & $\mathrm{x}$ & $\mathrm{x}$ & $\begin{array}{l}\text { Socio-economic determinants; occupational risk (frontline); } \\
\text { barriers to healthcare }\end{array}$ \\
\hline Clarke (Clarke et al., 2020) & $\begin{array}{l}\text { USA and } \\
\text { Canada }\end{array}$ & Refugee & $\mathrm{x}$ & $\mathrm{x}$ & $\mathrm{x}$ & $\mathrm{x}$ & $\begin{array}{l}\text { Socio-economic determinants; occupational risk; barriers to } \\
\text { healthcare; co-morbidities }\end{array}$ \\
\hline Wang (Wang et al., 2020) & Global & Migrant workers & & $\mathrm{x}$ & $\mathrm{x}$ & $\mathrm{x}$ & $\begin{array}{l}\text { Socio-economic determinants; occupational risk; barriers to } \\
\text { healthcare }\end{array}$ \\
\hline $\begin{array}{l}\text { Kanlungan Filipino Consortium } \\
\text { (Kanlungan Filipino Consortium } \\
\text { 2020) }\end{array}$ & UK & $\begin{array}{l}\text { Filipino precarious } \\
\text { migrants }\end{array}$ & & $\mathrm{x}$ & $\mathrm{x}$ & $\mathrm{x}$ & $\begin{array}{l}\text { Occupational risk (frontline, job security); barriers to } \\
\text { healthcare; overcrowding }\end{array}$ \\
\hline Capps (Capps R, Gelatt, 2020) & USA & Migrant workers & & $\mathrm{x}$ & & & Barriers to healthcare (immigration status) \\
\hline Zelaya (Zelaya et al. 2020) & USA & $\begin{array}{l}\text { Undocumented } \\
\text { migrants }\end{array}$ & & $\mathrm{x}$ & & & Barriers to healthcare (immigration status) \\
\hline Davis (Davis, 2020) & $\begin{array}{l}\text { Massachusetts, } \\
\text { US }\end{array}$ & Migrant households & & $\mathrm{x}$ & & & Barriers to healthcare (immigration status; language/cultural) \\
\hline Patel (Patel et al., 2020) & UK & Migrants and refugees & & $\mathrm{x}$ & $\mathrm{x}$ & & $\begin{array}{l}\text { Barriers to healthcare (immigration status; language/cultural); } \\
\text { conditions in detention centres (overcrowding) }\end{array}$ \\
\hline Cross (Cross and Benson, 2020) & US & $\begin{array}{l}\text { Undocumented } \\
\text { migrants }\end{array}$ & & $\mathrm{x}$ & $\mathrm{x}$ & $\mathrm{x}$ & $\begin{array}{l}\text { Barriers to healthcare (immigration status); occupational risk } \\
\text { (frontline); conditions in detention centres }\end{array}$ \\
\hline Gosselin (Gosselin et al., 2020) & France & Migrants & $\mathrm{x}$ & $\mathrm{x}$ & $\mathrm{x}$ & $\mathrm{x}$ & $\begin{array}{l}\text { Co-morbidities; barriers to healthcare (language/cultural); } \\
\text { occupational risk (frontline); conditions in camps and detention } \\
\text { centres }\end{array}$ \\
\hline Elisabeth (Elisabeth et al., 2020) & Sweden & Refugees & $\mathrm{x}$ & $\mathrm{x}$ & $\mathrm{x}$ & & $\begin{array}{l}\text { Co-morbidities; socio-economic determinants (poverty, } \\
\text { overcrowding); barriers to healthcare (language/cultural) }\end{array}$ \\
\hline Tadolini (Tadolini et al., 2020) & Global & Migrants & $\mathrm{x}$ & & & & Co-infection with tuberculosis \\
\hline Motta (Motta et al., 2020) & Global & Migrants & $\mathrm{x}$ & & & & Co-infection with tuberculosis \\
\hline Dias (Dias et al., 2020) & Portugal & Migrants & & $\mathrm{x}$ & $\mathrm{x}$ & $\mathrm{x}$ & Living conditions; occupational risk; barriers to healthcare \\
\hline Iacobucci (Iacobucci, 2020) & Greece & Refugees in camps & $\mathrm{x}$ & $\mathrm{x}$ & $\mathrm{x}$ & & Conditions in camps (overcrowding, healthcare); co-morbidities \\
\hline $\begin{array}{l}\text { Hargreaves (Hargreaves et al., } \\
\text { 2020) }\end{array}$ & Global & Migrants and refugees & $\mathrm{x}$ & $\mathrm{x}$ & $\mathrm{x}$ & $\mathrm{x}$ & $\begin{array}{l}\text { Conditions in camps (overcrowding, sanitation, healthcare); } \\
\text { occupational risk (living conditions); co-morbidities }\end{array}$ \\
\hline Jozaghi (Jozaghi and Dahya, 2020) & $\begin{array}{l}\text { Global, with } \\
\text { focus on } \\
\text { Canada }\end{array}$ & Refugees in camps & $\mathrm{x}$ & & $\mathrm{x}$ & & Conditions in camps (overcrowding, sanitation); co-morbidities \\
\hline ACAPS (ACAPS 2020) & Greece & Refugees in camps & & & $\mathrm{x}$ & & Conditions in camps (overcrowding, sanitation, healthcare) \\
\hline $\begin{array}{l}\text { Wood (Wood and } \\
\text { Devakumar, 2020) }\end{array}$ & England & Migrant children & & $\mathrm{x}$ & & & Barriers to healthcare (immigration status) \\
\hline Germain (Germain and Yong, 2020) & England & Migrant women & & $\mathrm{x}$ & & & Barriers to healthcare (immigration status) \\
\hline Cholera (Cholera et al., 2020) & USA & Migrant children & & $\mathrm{x}$ & $\mathrm{x}$ & & $\begin{array}{l}\text { Barriers to healthcare (immigration status); multigenerational } \\
\text { households }\end{array}$ \\
\hline
\end{tabular}




\begin{tabular}{|c|c|c|c|c|c|c|c|}
\hline \multirow[t]{2}{*}{ Authors } & \multirow[t]{2}{*}{ Location } & \multirow[t]{2}{*}{ Population } & \multicolumn{5}{|l|}{ Risk factors } \\
\hline & & & $\begin{array}{l}\text { Co- } \\
\text { morbidities }\end{array}$ & $\begin{array}{l}\text { Health } \\
\text { seeking and } \\
\text { health care }\end{array}$ & $\begin{array}{l}\text { Social and } \\
\text { cultural }\end{array}$ & Occupation & Details \\
\hline Bakhiet (Bakhiet et al. 2020) & USA & Refugees & & $\mathrm{x}$ & & & $\begin{array}{l}\text { Barriers to healthcare (immigration status, other } \\
\text { structural/cultural) }\end{array}$ \\
\hline $\begin{array}{l}\text { Greenaway (Greenaway et al., } \\
\text { 2020) }\end{array}$ & Global & Migrants & $\mathrm{x}$ & $\mathrm{x}$ & $\mathrm{x}$ & $\mathrm{x}$ & Socio-economic determinants; barriers to healthcare \\
\hline Wilson (Wilson et al., 2020) & USA & $\begin{array}{l}\text { Undocumented } \\
\text { migrants }\end{array}$ & & $\mathrm{x}$ & & & Barriers to healthcare (immigration status) \\
\hline Behbahani (Behbahani et al., 2020) & New York, USA & Migrants & & $\mathrm{x}$ & & & Barriers to healthcare (immigration status, language) \\
\hline Lopez (Lopez and Holmes, 2020) & USA & Migrants & & $\mathrm{x}$ & & & Barriers to healthcare (immigration status) \\
\hline Lam (Lam, 2020) & Canada & Migrant sex workers & & $\mathrm{x}$ & & $\mathrm{x}$ & Barriers to healthcare (immigration status); occupational risk \\
\hline Doyle (Doyle, 2020) & Canada & Migrant workers & & $\mathrm{x}$ & $\mathrm{x}$ & $\mathrm{x}$ & $\begin{array}{l}\text { Barriers to healthcare (immigration status); occupational risk; } \\
\text { overcrowding }\end{array}$ \\
\hline $\begin{array}{l}\text { Bodenmann (Bodenmann et al., } \\
\text { 2020) }\end{array}$ & $\begin{array}{l}\text { Vaud, } \\
\text { Switzerland }\end{array}$ & Forced migrants & & $\mathrm{x}$ & $\mathrm{x}$ & & $\begin{array}{l}\text { Barriers to healthcare (cultural, language); socio-cultural } \\
\text { factors; overcrowding }\end{array}$ \\
\hline $\begin{array}{l}\text { Institut For Menneske Rettigheder } \\
\text { (Institut for Menneskerettigheder } \\
\text { 2020) }\end{array}$ & Denmark & Migrants & & $\mathrm{x}$ & $\mathrm{x}$ & & $\begin{array}{l}\text { Language and cultural barriers to communication of govt } \\
\text { guidance }\end{array}$ \\
\hline Ceccarelli (Ceccarelli et al., 2020) & $\begin{array}{l}\text { Rocca di Papa, } \\
\text { Italy }\end{array}$ & $\begin{array}{l}\text { Migrants in reception } \\
\text { centre }\end{array}$ & & $\mathrm{x}$ & $\mathrm{x}$ & & Low awareness of pandemic \\
\hline Guo (Guo et al., 2020) & Spain & Chinese migrants & & $\mathrm{x}$ & $\mathrm{x}$ & & High awareness of pandemic and compliance \\
\hline Zhang (Zhang and Zhao, 2020) & Global & Chinese migrants & & $\mathrm{x}$ & $\mathrm{x}$ & & High awareness of pandemic and compliance \\
\hline Vonen (Vonen et al., 2020) & Europe & Refugees in camps & & $\mathrm{x}$ & $\mathrm{x}$ & & Conditions in camps (overcrowding, sanitation, healthcare) \\
\hline Medact (Medact 2020) & Europe & Refugees in camps & & $\mathrm{x}$ & $\mathrm{x}$ & & Conditions in camps (testing/ healthcare) \\
\hline $\begin{array}{l}\text { Hernandez Suarez } \\
\text { (Hernandez-Suarez et al., 2020) }\end{array}$ & Global & Refugees in camps & & $\mathrm{x}$ & & & Potential for transmission in camps; healthcare impact \\
\hline $\begin{array}{l}\text { Hargreaves (Hargreaves et al., } \\
\text { 2020) }\end{array}$ & Europe & $\begin{array}{l}\text { Refugees in camps } \\
\text { and detention centres }\end{array}$ & & $\mathrm{x}$ & $\mathrm{x}$ & & $\begin{array}{l}\text { Conditions in camps and detention centres (overcrowding, } \\
\text { sanitation, healthcare) }\end{array}$ \\
\hline Alawa (Alawa et al., 2020) & Global & Refugees in camps & & $\mathrm{x}$ & $\mathrm{x}$ & & Conditions in camps (overcrowding, sanitation, healthcare) \\
\hline Peprah (Peprah, 2020) & Global & $\begin{array}{l}\text { Older refugees in } \\
\text { camps }\end{array}$ & & $\mathrm{x}$ & $\mathrm{x}$ & & Conditions in camps (sanitation, healthcare, trauma) \\
\hline $\begin{array}{l}\text { Spernovasilis (Spernovasilis et al., } \\
\text { 2020) }\end{array}$ & Greece & Refugees in camps & & $\mathrm{x}$ & $\mathrm{x}$ & & Conditions in camps (overcrowding, sanitation, healthcare) \\
\hline Kondilis (Kondilis et al., 2020) & Greece & Refugees in camps & & $\mathrm{x}$ & $\mathrm{x}$ & & Conditions in camps (overcrowding, sanitation, healthcare) \\
\hline The Lancet (The Lancet 2020) & Global & Refugees in camps & & $\mathrm{x}$ & $\mathrm{x}$ & & Conditions in camps (overcrowding, sanitation, healthcare) \\
\hline Gilman (Gilman et al., 2020) & Moira, Greece & Refugees in camps & & $\mathrm{x}$ & $\mathrm{x}$ & & $\begin{array}{l}\text { Potential for transmission in camps (due to overcrowding, } \\
\text { sanitation, healthcare) }\end{array}$ \\
\hline Alemi (Alemi et al., 2020) & Global & Refugees in camps & $\mathrm{x}$ & $\mathrm{x}$ & $\mathrm{x}$ & & $\begin{array}{l}\text { Conditions in camps (overcrowding, sanitation, stigma deterring } \\
\text { health seeking); comorbidities }\end{array}$ \\
\hline Logar (Logar and Leese, 2020) & Italy & $\begin{array}{l}\text { Child migrants in } \\
\text { detention centres }\end{array}$ & $\mathrm{x}$ & & $\mathrm{x}$ & & Conditions in detention centres (overcrowding); comorbidities \\
\hline Meyer (Meyer et al., 2020) & USA & $\begin{array}{l}\text { Migrants in detention } \\
\text { centres }\end{array}$ & & $\mathrm{x}$ & $\mathrm{x}$ & & Conditions in detention centres (overcrowding, healthcare) \\
\hline Irvine (Irvine et al., 2020) & USA & $\begin{array}{l}\text { Migrants in detention } \\
\text { centres }\end{array}$ & & $\mathrm{x}$ & & & $\begin{array}{l}\text { Potential for transmission in detention centres; healthcare } \\
\text { impact }\end{array}$ \\
\hline Schotland (Schotland, 2020) & USA & $\begin{array}{l}\text { Migrants in detention } \\
\text { centres }\end{array}$ & & & $\mathrm{x}$ & & Conditions in detention centres (overcrowding, sanitation) \\
\hline Mosca (Mosca et al., 2020) & Global & Irregular migrants & & $\mathrm{x}$ & $\mathrm{x}$ & & $\begin{array}{l}\text { Conditions in detention centres (overcrowding, sanitation), } \\
\text { barriers to healthcare (immigration status) }\end{array}$ \\
\hline Lenzer (Lenzer, 2020) & USA & $\begin{array}{l}\text { Migrants in detention } \\
\text { centres }\end{array}$ & & $\mathrm{x}$ & & & Conditions in detention centres (healthcare) \\
\hline $\begin{array}{l}\text { Emelurumonye } \\
\text { (Emelurumonye and } \\
\text { Miglietta, 2020) }\end{array}$ & Italy & $\begin{array}{l}\text { Migrants in detention } \\
\text { centres }\end{array}$ & & $\mathrm{x}$ & $\mathrm{x}$ & & $\begin{array}{l}\text { Conditions in detention centres (overcrowding, sanitation, } \\
\text { healthcare) }\end{array}$ \\
\hline $\begin{array}{l}\text { Emelurumonye } \\
\text { (Emelurumonye and } \\
\text { Miglietta, 2020) }\end{array}$ & Italy & $\begin{array}{l}\text { Migrants in detention } \\
\text { centres }\end{array}$ & & $\mathrm{x}$ & $\mathrm{x}$ & & $\begin{array}{l}\text { Conditions in detention centres (overcrowding, sanitation, } \\
\text { healthcare) }\end{array}$ \\
\hline
\end{tabular}




\begin{tabular}{l}
\hline Armitage (Armitage and \\
Nellums, 2020) \\
Ramírez-Cervantes \\
(Ramírez-Cervantes et al., 2020) \\
Valeriani (Valeriani et al., 2020) \\
Giordano (Giordano, 2020) \\
Kuhlmann (Kuhlmann et al., 2020) \\
Kerwin (Kerwin and Warren, 2020) \\
Bureau of Policy \& Research \\
(Bureau of Policy and Research \\
2020) \\
Haley (Haley et al., 2020)
\end{tabular}

Haley (Haley et al., 2020)

Mares (Mares, 2020)

Lee (Lee et al., 2020)

\section{Chandratre (Chandratre and}

\section{Soman, 2020$)$}

St-Denis (St-Denis, 2020)

Tayaben (Tayaben an

Younas, 2020)

N (Nezafat Maldonado et al., 2020)

Alahmad (Alahmad et al., 2020)

Wong (Wong CL and Chow, 2020)

Kong (Kong et al., 2020)

Rizzolo (Rizzolo et al., 2020)

Orcutt (Orcutt et al., 2020)

Carruthers (Carruthers et al., 2020)

Carruthers (Carruthers et al., 2020)

Guadagno (Guadagno, 2020)

Esegbona-Adeigbe

(Esegbona-Adeigbe, 2020)

Ali (Ali et al., 2020)

OECD (OECD 2020)

Turcotte (Turcotte and

Savage, 2020)

Cleveland (Cleveland et al., 2020)

Gottlieb (Gottlieb et al., 2020)

Nobody Left Outside (Nobody Left Outside 2020)
Location

Population

Risk factors

Co-

Health

Social and

Occupation

Details

health care

$\begin{array}{ll}\text { Europe } & \begin{array}{l}\text { Gypsy, Roma and } \\ \text { Traveller populatio }\end{array}\end{array}$

Madrid, Spain

Treller population

Sweden

Belgium

Migrants

$\mathrm{x}$

Migrants

Migrant care workers

New York, USA Migrant workers

Canada

Migrant farmworkers

Vermont, USA

Migrant farmworkers

USA

Migrant farmworkers

USA

Migrant physicians

Canada

Global

Migrant workers

Migrant nurses

Migrants

Migrant workers

South Asian migrants

Chinese migrants

Undocumented

migrants

Migrants and refugees

$\mathrm{x}$

USA

Global

Greece

Greece

Globa

Refugees and asylum

seekers

Refugees and asylum

seekers

UK

Migrants and asylum

seekers

Migrant workers

Saudi Arabia

Migrants

Migrants

Canada

Montreal,

Canada

Germany

Informants incl.

migrants

Migrants

Undocumented

migrants

migrants

$\mathrm{x}$

\section{Living conditions; barriers to healthcare}

Socio-economic factors; living conditions (overcrowding)

Barriers to healthcare (cultural, language)

Occupational risk (frontline, job security)

Occupational risk (frontline, job security)

Occupational risk (frontline/essential, HCWs, job security)

Occupational risk (frontline)

Occupational risk (frontline, job security); overcrowding healthcare access (immigration status)

Occupational risk (frontline, job security); overcrowding.

healthcare access (immigration status)

Occupational risk (frontline), overcrowding; healthcare access

(cultural, technological)

Occupational risk (HCWs)

Occupational risk (physical distancing)

Occupational risk (HCWs)

Healthcare access (language)

Occupational risk (frontline, job security); healthcare access (structural, cultural, language)

High awareness of pandemic and self-efficacy

Healthcare seeking attitudes (Chinese medicine)

Co-morbidities (kidney failure, emergency-only haemodialysis)

Socio-economic determinants; barriers to healthcare; conditions in camps

Conditions in camps (overcrowding, sanitation, healthcare); healthcare access (immigration status)

Conditions in camps (overcrowding, sanitation, healthcare); healthcare access (immigration status, cultural, language) Occupational risk (frontline, job security); healthcare access (immigration status, cultural); overcrowding; conditions in camps and detention centres Impact on healthcare access

Occupational risk (frontline); healthcare access (immigration status); overcrowding

Occupational risk (frontline, job security); overcrowding:

socio-economic factors

Occupational risk (frontline, $\mathrm{HCWs}$ )

Socio-economic determinants; occupational risk; overcrowding; barriers to healthcare (language, immigration status)

Socio-economic determinants; occupational risk; overcrowding; barriers to healthcare

Socio-economic determinants; overcrowding; occupational risk barriers to healthcare 


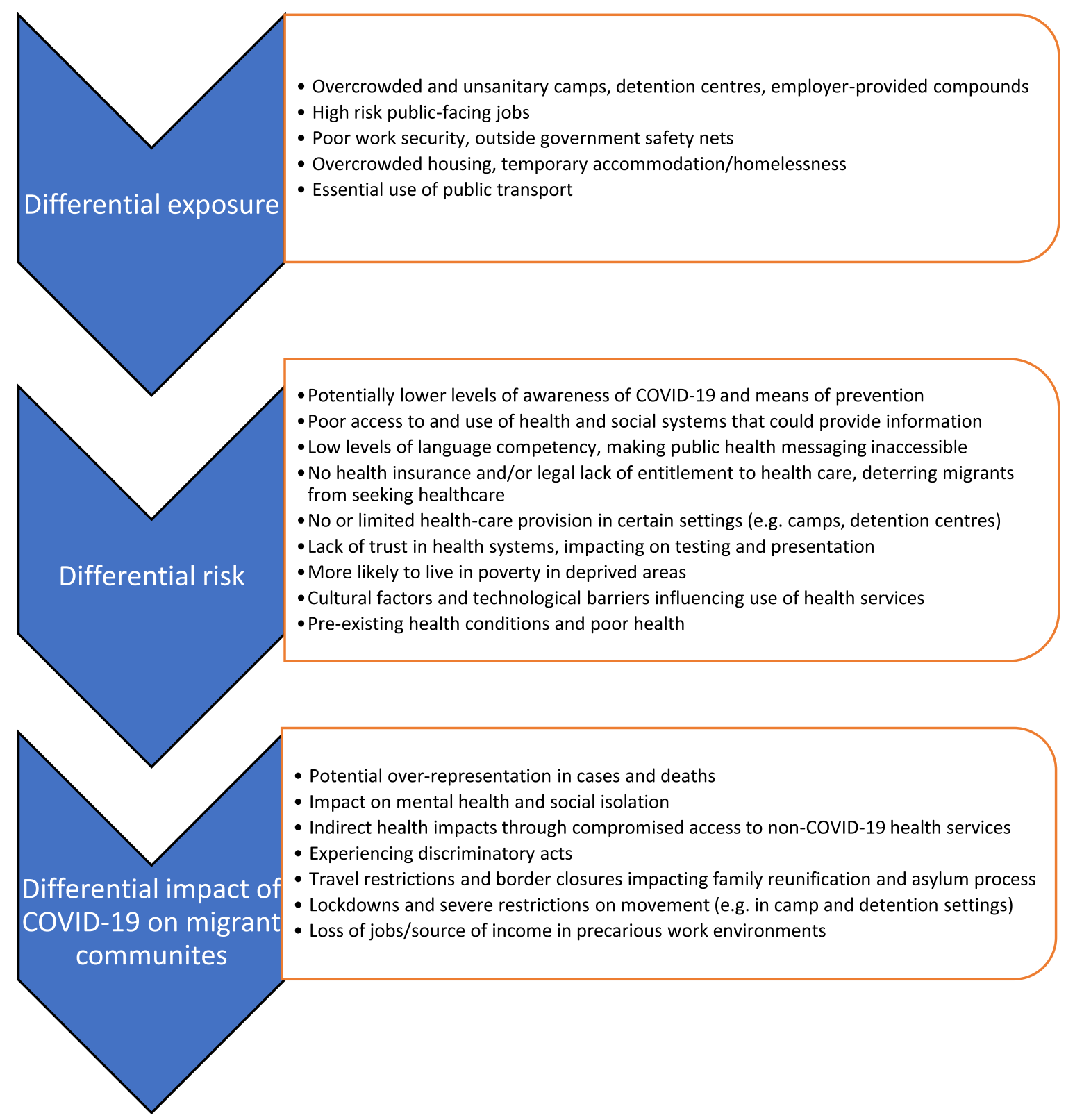

Fig. 2. Migrant-specific risk factors and vulnerabilities identified in included literature.

said they would be 'extremely worried' for this reason (Goodman et al., 2020).

Healthcare access for migrants and refugees in camp settings can be limited, lacking medical personnel, equipment and pharmaceuticals (Vonen et al., 2020), with poor or absent testing facilities (Medact, 2020). A modelling study has suggested that once the virus enters refugee camps, it can spread quickly, overwhelming hospitals and healthcare facilities (Hernandez-Suarez et al., 2020).

With routine services closed due to the pandemic, concerns have been raised that migrants have struggled to navigate the new systems (Doctors of the World 2020, Valeriani et al., 2020, EsegbonaAdeigbe, 2020, Nobody Left Outside 2020) and it has exacerbated migrants' exclusion from health services (Desai and Samari, 2020, Santos et al., 2020, Aragona et al., 2020, Clarke et al., 2020, Devillanova et al., 2020). Migrants may experience challenges in accessing healthcare remotely (Doctors of the World 2020, BrickhillAtkinson and Hauck, 2020, Page et al., 2020, Langellier, 2020, Wernly et al., 2020); however, telemedicine may also offer opportuni- ties that need to be further explored in these populations (Warner et al., 2020, Green et al., 2020).

Migrants often have difficulties understanding public health messaging due to cultural and language barriers (Doctors of the World 2020, Cholera et al., 2020, Bodenmann et al., 2020). Public health guidance in many countries was not initially tailored to the needs of migrant and ethnic minority groups (Doctors of the World 2020, Nezafat Maldonado et al., 2020); in the UK non-governmental organisations (NGOs) translated material into 51 languages to make it more accessible (Patel et al., 2020). In Denmark, a series of qualitative interviews with migrants found that they felt uncertain regarding government guidance for COVID-19; although written material was translated into 19 languages, it was not effectively disseminated (Institut for Menneskerettigheder 2020). In Montreal, Canada, it took two months after lockdown started for the Public Health directorate to publish official multilingual fact sheets on COVID-19 guidelines, and information phone lines only operate in French and English. Those who had arrived most recently, had lower language (French/English) ability or 
lower literacy had more difficulty accessing local COVID-19 information (Cleveland et al., 2020). In a rapid review to assess communications targeting migrant populations across Council of Europe Member States only $48 \%$ (23/47) translated information into at least one foreign language (Nezafat Maldonado et al., 2020). Information on testing or healthcare entitlements in common migrant languages was only found in $6 \%(3 / 47)$ of countries and no government produced risk communications on disease prevention targeting people in refugee camps or informal settlements. Poor language competence was linked to low testing rates in two studies (Guttmann et al., 2020, Kim et al., 2020).

A potential lack of knowledge and awareness of COVID-19 among migrant groups or spread of misinformation has been reported (Doctors of the World 2020). For example, in qualitative interviews conducted in a migrant reception centre in Rocca di Papa, Italy between February and July 2020, there was low awareness of the danger of the pandemic, especially among migrants from sub-Saharan Africa (Ceccarelli et al., 2020). There is some evidence that traditional Chinese medicine may have been used as a means of preventing COVID19 among Chinese immigrants in Canada (Bodenmann et al., 2020, Kong et al., 2020). Conversely, migrants may be more likely to comply with preventative measures such as mask wearing, especially those migrating from Asian countries where this is more of a cultural norm (Guo et al., 2020, Zhang and Zhao, 2020). A questionnaire among 352 Indian, Pakistani, and Nepalese migrants in Hong Kong found migrants expressed certain misconceptions regarding the prevention of COVID19 infection, but perceived the risk of disease as mild, had positive attitudes regarding its prevention, and implemented recommended diseasepreventive measures (Wong and Chow, 2020).

\subsubsection{Camps, detention centres, and overcrowded accommodation}

Refugee camps are typically crowded, and are often built quickly and with little regard to such things as tent spacing. In these settings, where social distancing and personal hygiene is difficult, the spread of COVID-19 is facilitated (Greenaway et al., 2020, Iacobucci, 2020, Hargreaves et al., 2020, Jozaghi and Dahya, 2020, ACAPS 2020, Vonen et al., 2020, Hargreaves et al., 2020, Alawa et al., 2020, Peprah, 2020, Spernovasilis et al., 2020, Kondilis et al., 2020, The Lancet 2020, Gilman et al., 2020, Alemi et al., 2020, Carruthers et al., 2020, Carruthers et al., 2020, Veizis, 2020). For example, the Moria camp in Greece had an estimated population density of 133,000 per $\mathrm{km}^{2}$, with reports of one water tap shared between 1,300 people in some areas of the camp (ACAPS 2020).

Conditions in detention or reception facilities are similarly conducive to the spread of COVID-19, with confined and poorly ventilated spaces (Doctors of the World 2020, Cross and Benson, 2020, Logar and Leese, 2020, Meyer et al., 2020, Irvine et al., 2020, Schotland, 2020, Mosca et al., 2020). In the US, there have been concerns that ICE facilities have violated their own standards as well as those from the Center for Disease Prevention and Control (CDC), for failing to test sick detainees (Openshaw and Travassos, 2020, Lenzer, 2020). Living conditions in reception facilities in Europe are overcrowded (European Centre for Disease Prevention and Control 2020, Emelurumonye and Miglietta, 2020, Emelurumonye and Miglietta, 2020). Gypsy, Roma and Traveller populations are also at risk due to living in potentially crowded conditions, their nomadic way of life, and reduced engagement with health services (Doctors of the World 2020, Armitage and Nellums, 2020). Many migrant workers live in employer-provided shared accommodation, considered high-risk for COVID-19 (Doyle, 2020, Mares, 2020, Haley et al., 2020, Lee et al., 2020).

Migrants in the community are more likely to live in shared or overcrowded accommodation than non-migrants in host countries (Doctors of the World 2020). 235 (59\%) of 399 of patients admitted to a medicalised hotel in Madrid in March to May 2020 were migrants: the main reason for referral was a lack of housing that supported quarantining, for example due to overcrowding, which was correlated with migrant status ( $\chi^{2}=19.4, p<0.01$ ) (Ramírez-Cervantes et al., 2020). At a clinic in Milan, the proportion of undocumented migrants who were homeless nearly doubled from $8.8 \%$ to $17.1 \%$ in the months immediately before and during/after lockdown (Devillanova et al., 2020). In a survey of precarious Filipino migrants in the UK, most of whom were undocumented migrants, $58 \%$ of respondents lived in shared houses, 1 in 5 were homeless, had no fixed address, or were staying temporarily with friends (on average sharing a bedroom with 1-2 others) (Kanlungan Filipino Consortium 2020).

Across all OECD countries, migrants are more likely to live in substandard accommodation (23\% versus $19 \%$ in the native-born) and twice as likely to live in overcrowded dwellings (17\% versus $8 \%$ ) which could influence transmission and exposure (OECD, 2020). Living in neighbourhoods with higher household density was associated with higher positivity rates for COVID-19 in Ontario, Canada, but especially for migrants (Guttmann et al., 2020). Migrants are also more likely to live in multigenerational houses, with implications for transmission from younger to older and more vulnerable household members (Cholera et al., 2020, Langellier, 2020).

\subsubsection{Occupational risk}

Migrants are disproportionately represented in front-line publicfacing jobs, such as in the fields of healthcare, social work, hospitality, retail, delivery and household services, and in menial jobs that can place them at increased exposure of COVID-19 (Guadagno, 2020, Cross and Benson, 2020, Haley et al., 2020, Giordano, 2020, Kuhlmann et al., 2020, Ali et al., 2020, Gottlieb et al., 2020). On average, 13\% of all key workers in the EU are immigrants (Migration Data Portal 2020). Based on 2018 US Census Bureau data for a report on COVID-19 impacts, $69 \%$ of all immigrants in the US labour force and $74 \%$ of undocumented workers were reported to be essential workers, compared to $65 \%$ of the native-born labour force; $70 \%$ of refugees and $78 \%$ of Black refugees are essential workers (Kerwin and Warren, 2020), with non-US-citizens making up $9 \%$ of the labour force but $22 \%$ of workers in the agricultural industry, for example (Langellier, 2020). In New York, the hardest hit US city during the first wave of the pandemic, $50 \%$ of non-governmental frontline workers are migrants (Bureau of Policy and Research 2020).

Migrants may need to carry on working or risk losing their job (Kanlungan Filipino Consortium 2020, Giordano, 2020). This is especially true for migrants in informal 'no work, no pay', with precarious contracts, or exploitative employment, including undocumented migrants who fall outside of government safety nets (Kanlungan Filipino Consortium 2020, Bureau of Policy and Research 2020). A Canadian analysis found that workers in low-income occupations (especially women, migrants, and visible minority groups) are employed in occupations that put them at greater risk of exposure to COVID-19 than other workers; low-income workers may face financial disincentives for absence even if they are sick or vulnerable, increasing workplace transmission (Armitage and Nellums, 2020). Migrants are also potentially more likely to rely on public transport to get to work, again increasing their possible exposure to COVID-19 infection (Langellier, 2020).

Not all migrants are unskilled or work in low-skilled occupations, however. A substantial proportion of doctors, nurses, and other medical specialists in countries such as Germany, France, US, Canada, and UK are migrants (Migration Data Portal 2020, Chandratre and Soman, 2020). In Canada (2016 data), more than a third of nurse aides, orderlies and patient service associates were migrants, with Black and Filipino women particularly over-represented (Turcotte and Savage, 2020). Data are lacking on the impact of COVID-19 on this occupational group, and on hospital cleaning and maintenance staff who in many EU countries also tend to be migrants. In a Canadian analysis, migrants in health occupations were found to have a slightly higher mean occupational risk of exposure to diseases/infections such as COVID-19 than Canadianborn workers (St-Denis, 2020). Employment as a healthcare worker in Ontario accounted for a disproportionate number of COVID-19 cases among migrants, especially women (Guttmann et al., 2020). Concerns have also been raised about inadequate access to or use of PPE, overrep- 
resentation of migrants in low paying paramedical roles, or difficulties in self-isolating because of staff shortages at the start of the pandemic (Greenaway et al., 2020, Tayaben and Younas, 2020).

Living in low-income neighbourhoods was strongly correlated with test positivity for newly-arrived migrants but not for Canadian-born and long-term residents (Guttmann et al., 2020). In addition, the association between percentage of immigrants living in a given area of Ontario and diagnoses of COVID-19 is attenuated when adjusting for covariates such as household income, educational attainment, and household density (Sundaram et al., 2020). In Swedish data, socioeconomic status (including disposable income and employment status), number of working age household members and neighbourhood population density attenuated up to half of the increased COVID-19 mortality risk, but not all-cause mortality (Rostila et al., 2020), indicating that these factors play a role but cannot account entirely for the observed disparity.

\section{Discussion}

This systematic review is the first attempt to bring together global datasets on the impact of COVID-19 on migrants, and to assess the critical risk factors and vulnerabilities involved, in what is a rapidly evolving field. We found that migrants are at high risk of COVID-19 infection and over-represented in confirmed COVID-19 cases, with data suggesting an elevated risk for COVID-19 among undocumented migrants, migrant health and care workers, and migrants housed in camps and labour compounds. Available data point to a similarly disproportionate representation of migrants in reported COVID-19 deaths, as well as increased all-cause mortality in migrants in reporting countries in 2020, though data are limited. In general, migrants were found to have higher levels of many of the risk factors and vulnerabilities for COVID-19, as a result of increased exposure due to high-risk or precarious occupations, overcrowded accommodation, legal-administrative barriers to healthcare services and low levels of language competence, all of which have a potentially negative impact on awareness of the problem and/or ability to take remedial action - including testing uptake and activities to reduce exposure. These data are of immediate relevance to national public health responses, be it in terms of policies or programmatic actions tailored to reach migrants.

In the most recent and largest systematic review of $18,728,893$ patients in datasets reporting clinical outcomes for COVID-19 by ethnicity (42 studies from the US, 8 from the UK to $31 \mathrm{Aug}$ ), authors report an increased risk of infection in Black and Asian ethnicities (Asian pooled adjusted RR 1.50 [95\% CI 1.24-1.93]; Black 2.02 [1.67-2.45]) compared to White individuals, with Asian individuals being at higher risk of hospital admission to intensive care and risk of death, even after adjusting for confounders such as age, sex, and co-morbidities (Sze S and Nevill, 2020). Other research has highlighted high seroprevalence rates for COVID-19 in people living in precarious situations, suggesting overexposure of marginalised groups (Roederer et al., 2020). These datasets will include migrants as a subpopulation, but do not disaggregate by migrant status. Our analysis suggests that migrants specifically have an increased risk of infection and points to striking increases in all-cause mortality data among certain migrant groups in the few countries that have reported on this in 2020. More robust data on cases, testing uptake, hospitalisations and deaths from COVID-19 among migrants is therefore warranted and considered urgent. There is also a need to strengthen data systems in HICs so as to better understand the distribution of particular health outcomes in migrant populations, not only with respect to COVID-19 but in other disease areas as well.

In this analysis, we report data that defines a unique set of risk factors and vulnerabilities experienced by migrants in HICs that are influencing exposure and outcomes to COVID-19. These risk factors and vulnerabilities are, in large part, related to their health and social situation in the host country, and the barriers to accessing health systems (including preventative testing and treatment) that they face, which have been well reported for other infectious diseases (Noori et al., 2020). Risk fac- tors include lower levels of language proficiency rendering public health messaging inaccessible. Low host country language competence, which is particularly the case with more recently arrived migrants, was seen to be associated with lower rates of testing in two studies, but higher rates of positivity when tested (Guttmann et al., 2020, Kim et al., 2020). We know that few countries specifically targeted public health messaging to migrants, which could have resulted in their exclusion from the larger public health response (Nezafat Maldonado et al., 2020). Precarious occupations and social situations mean that public health proposals such as work-from-home, self-isolation, avoidance of public transport, and rapid testing uptake are not relevant for many migrants and point to a type and degree of exclusion or restricted access to mainstream health systems.

Tens of thousands of migrants in HICs are excluded or restricted from accessing mainstream health systems because of their immigration status, likely a major barrier to accessing testing and treatment, and eventual vaccine roll out. Previous data for other infections has shown migrants may be late presenters to health services (Potter et al., 2020), presenting only where necessary due to concerns around immigration and lack of trust, lack of knowledge of the health system, and barriers to registration and access. These findings strongly support arguments for more tailored and targeted public health initiatives to these groups, including information and communication around testing, contact tracing, isolation, and when to present, as well as tackling misinformation. Actions on behalf of migrants should be undertaken with and through trusted community channels, and developed through direct engagement with at-risk migrant groups. Several groups have called for the temporary suspension of policies that exclude migrants from health systems during the pandemic (Orcutt et al., 2020), something several countries have done, along with stressing the importance of inclusion of these groups in ongoing protective measures, information campaigns and health services provision ((The Migrant and Ethnic Health Section of the European Public Health Association (EUPHA) 2020, The Migrant and Ethnic Health Section of the European Public Health Association (EUPHA) 2020)). WHO and other agencies have reinforced the need to ensure migrants in camps and closed facilities are offered screening, triage testing, and provided with care (Chandratre and Soman, 2020). UN agencies have also stressed the human rights of refugees and migrants and the need to ensure that COVID-19 responses respect these rights (UNHCR, IOM, OHCHR, WHO 2020).

This review has some inevitable limitations. It was not possible to engage an expert in every HIC and as a result some national statistics and grey literature may have been missed. However, we engaged widely through our international networks to source local literature, and the WHO database sources both peer-reviewed, pre-prints, and grey literature from a diverse range of databases that would not normally have been searched individually for a systematic review. We are therefore confident that we have included the majority of datasets available to 18 Nov. In addition, we have included non-peer reviewed grey literature and pre-prints in the narrative synthesis with obvious limitations. Due to the rapidly evolving nature of the pandemic we felt this was justified and strengthens our description of the current situation facing migrants in HICs. In Table 1 and Supplementary Table 1 we have clearly stated all data sources and have given a quality appraisal score to them.

Panel 1 sets out some of the implications of this work for further research and for health policies. Understanding the lived experience of marginalised migrants will be vital to tackling issues around barriers to care (including of migrants with long-term symptoms), testing uptake, and obstacles and facilitators to eventual COVID-19 vaccination and ensuring good vaccine coverage of, and uptake by migrants and ethnic minorities (Paul et al., 2020). We believe our findings are of immediate relevance to the ongoing public health responses and should inform policies seeking to minimise exposure to COVID-19 in migrants and ensure their inclusion, through innovative and nuanced solutions with community engagement at their centre. 
Strengthen data collection and future planning

- Initiate large retrospective and prospective studies, disaggregating by migrant status, exploring disparities in testing and diagnosis, hospitalisations, and COVID-19-related deaths in migrants

- Collate and conduct ongoing analysis of data on COVID-19 vaccine uptake by migrants when vaccine roll out starts, to identify disparities early on so they can be addressed

- Ensure more consistent and complete incorporation of migrant status in surveillance and health information systems taking into account gender, ethnic, linguistic, educational and occupational diversity in migrant populations

- Create more empirical evidence on the link between risk factors identified in migrants and the role they play in driving disparities in clinical outcomes

- Development of pandemic preparedness plans that address migration and migrants, and can be shared by countries

Delivery of more effective public health messaging

- Co-produce carefully researched messaging on COVID-19 prevention, testing and treatment, contact tracing, and self-isolation with affected communities, tailored to different cultural and social realities and that considers the unique risk factors and vulnerabilities of migrant populations and offers them meaningful solutions and support mechanisms to reduce their exposure

- Ensure rapid quality translation and more effective dissemination of public health messaging and directives into common migrant languages

- Engagement of diverse high-risk migrant communities, through localised support and community champions, in defining how best to deliver credible information and support on COVID-19 testing, reducing their exposure, social support, and facilitating vaccine roll out, alongside exploring mechanisms to build trust in health systems and tackle misinformation

Better consider specific migrant groups

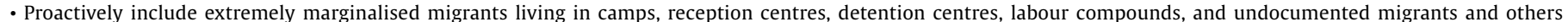
facing known structural barriers to health systems in the COVID-19 response

Long-term approaches to tackling disparities facing migrants in HICs

- Facilitate more inclusive and culturally competent health systems, now and beyond this pandemic

- Develop evidence-based inter-sectoral policies and strategies designed to improve the overall health and social conditions of migrants and respect the rights of migrants to basic human security in host countries

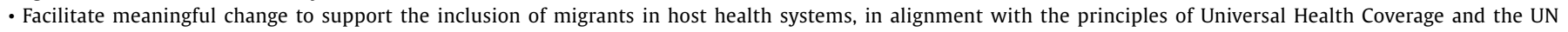
Sustainable Development Goals to leave no-one behind

\section{Contributions}

SH conceived the idea for the review and ran the literature searches. $\mathrm{SEH}, \mathrm{SH}$, and CC did the abstract and full text screening, data extraction, and synthesis. $\mathrm{AD}$ and $\mathrm{CC}$ did the quality appraisal. AFC, MO, MN, AR, $\mathrm{CG}, \mathrm{KB}, \mathrm{AV}, \mathrm{FW}$, IC-M, FS, and BN provided national datasets and grey literature. SEH and SH wrote a first draft of the paper with input from all authors.

\section{Funding}

NIHR; Academy of Medical Sciences.

\section{Conflicts of Interest}

The authors report no conflicts of interest to declare

\section{Acknowledgements}

SEH and AD are supported by Medical Research Council PhD studentships (MR/N013638/1). SH is funded by the NIHR (NIHR Advanced Fellowship NIHR300072) for this research project. The views expressed in this publication are those of the author(s) and not necessarily those of the NIHR, NHS or the UK Department of Health and Social Care. SH is also funded by the Academy of Medical Sciences (SBF005 $\backslash 1111$ ), and by the European Society of Clinical Microbiology and Infectious Diseases (ESCMID) through a joint ESCMID Study Group for Infections in Travellers and Migrants (ESGITM) and ESCMID Study Group for Mycobacterial Infections (ESGMYC) Research grant. AFC is funded by the Academy of Medical Sciences (SBF005 $\backslash 1111$ ) and the NIHR (NIHR300072). JC is funded by the NIHR (NIHR in-practice clinical fellowship NIHR300290). MO is supported by an Economic and Social Research Council (ESRC) PhD studentship. The authors would like to acknowledge Teymur Noori (ECDC) for his contribution.

\section{Supplementary materials}

Supplementary material associated with this article can be found, in the online version, at doi:10.1016/j.jmh.2021.100041.

\section{Appendix 1: Search Strategy}

TI:(Ancest* OR Diaspor* OR ethnic* OR Ethnoc* OR Ethnog* OR "Identity politics" OR Ingroups OR outgroups OR Intersectionality OR Kinship OR "Minority group*" 3 OR "minority population*" 2 OR minorities OR Multicultu* OR Polyethnic* OR "Population genetics" OR Race OR races OR racial OR Tribe* OR latino*) OR AB:(Ancest* OR Diaspor* OR ethnic* OR Ethnoc* OR Ethnog* OR "Identity politics" OR Ingroups OR Outgroups OR Intersectionality OR Kinship OR "Minority group*" $\sim 3$ OR "minority population*" 2 OR minorities OR Multicultu* OR Polyethnic* OR "Population genetics" OR Race OR races OR racial OR Tribe* OR latino*) OR "afro american*" 3 OR BAME OR latino* OR roma OR romani OR refugee* OR immigrant* OR "migrant" OR "displaced person" OR "displaced persons" OR "social determinant" $\sim 2$ OR "latin population" OR "latin group*" OR "people of color" OR "people of colour"

Appendix 2: World Bank High-Income Countries (2020)

\begin{tabular}{|c|c|c|}
\hline 1. Andorra & 36. Isle of Man & $\begin{array}{l}\text { 73. St Martin (French } \\
\text { part) }\end{array}$ \\
\hline $\begin{array}{l}\text { 2. Antigua and } \\
\text { Barbuda }\end{array}$ & 37. Israel & 74. Sweden \\
\hline 3. Aruba & 38. Italy & 75. Switzerland \\
\hline 4. Australia & 39. Japan & $\begin{array}{l}\text { 76. Trinidad and } \\
\text { Tobago }\end{array}$ \\
\hline 5. Austria & 40. Korea, Rep. & $\begin{array}{l}\text { 77. Turks and Caicos } \\
\text { Islands }\end{array}$ \\
\hline 6. The Bahamas & 41. Kuwait & $\begin{array}{l}\text { 78. United Arab } \\
\text { Emirates }\end{array}$ \\
\hline 7. Bahrain & 42. Latvia & 79. United Kingdom \\
\hline 8. Barbados & 43. Liechtenstein & 80. United States \\
\hline 9. Belgium & 44. Lithuania & 81. Uruguay \\
\hline 10. Bermuda & 45. Luxembourg & 82. Virgin Island \\
\hline $\begin{array}{l}\text { 11. British Virgin } \\
\text { Islands }\end{array}$ & 46. Macao SAR, China & \\
\hline $\begin{array}{l}\text { 12. Brunei } \\
\text { Darussalam }\end{array}$ & 47. Malta & \\
\hline 13. Canada & 48. Mauritius & \\
\hline 14. Cayman Islands & 49. Monaco & \\
\hline 15. Channel Islands & 50. Nauru & \\
\hline 16. Chile & 51. Netherlands & \\
\hline 17. Croatia & 52. New Caledonia & \\
\hline
\end{tabular}

(continued on next page) 


\begin{tabular}{ll}
\hline 18. Curacao & 53. New Zealand \\
19. Cyprus & 54. Northern Mariana \\
2slands & 55. Norway \\
20. Czech Republic & 56. Oman \\
21. Denmark & 57. Palau \\
22. Estonia & 58. Panama \\
23. Faroe Islands & 59. Poland \\
24. Finland & 60. Portugal \\
25. France & 61. Puerto Rico \\
26. French Polynesia & 62. Qatar \\
27. Germany & 63. Romania \\
28. Gibraltar & 64. San Marino \\
29. Greece & 65. Saudi Arabia \\
30. Greenland & 66. Seychelles \\
31. Guam & 67. Singapore \\
32. Hong Kong SAR, & 68. Sint Maarten \\
China & (Dutch part) \\
33. Hungary & 69. Slovak Republic \\
34. Iceland & 70. Slovenia \\
35. Ireland & 71. Spain \\
& 72. St Kitts and Nevis \\
\hline
\end{tabular}

\section{References}

Abubakar I, AR, Devakumar, D, et al., 2018. The UCL-lancet commission on migration and health: the health of a world on the move. Lancet 392 (10164), 2606-2654.

ACAPS. Greece - Displacement in Lesvos: Fires and COVID-19. 2020.

Alahmad, B, Kurdi, H, Colonna, K, Gasana, J, Agnew, J, Fox, MA., 2020. CVID-19 stressors on migrant workers in Kuwait: cumulative risk consideration. BMJ Global Health 5, e002995.

Alawa, J, Alawa, N, Coutts, A, Sullivan, R, Khoshnood, K, Fouad, FM., 2020. Addressing COVID-19 in humanitarian settings: a call to action. Confl Health 14, 64.

Aldridge, R, Nellums, LB, et al., 2018. Global patterns of mortality in international migrants: a systematic review and meta-analysis. Lancet North Am. Ed. 392, 2553-2566.

Alemi, Q, Stempel, C, Siddiq, H, Kim, E., 2020. Refugees and COVID-19: achieving a comprehensive public health response. Bull World Health Organ 98 (8), 510 A.

Ali, MA, Al-Khani, AM, Sidah, LA., 2020. Migrant health in Saudi Arabia during the COVID-19 pandemic. East Mediterr Health J. 26 (8), 879-880.

Alkhamis, MA, Al Youha, S, Khajah, MM, Haider, NB, Alhardan, S, Nabeel, A, et al., 2020. Spatiotemporal dynamics of the COVID-19 pandemic in the State of Kuwait. Int. J. Infect. Dis. 98, 153-160.

Alkhamis MA, AYS, Khajah, MM, et al., 2020. Spatiotemporal dynamics of the COVID_19 pandemic in the State of Kuwait. Int J. Infect. Dis. 98, 153-160.

Aragona, M, Barbato, A, Cavani, A, Costanzo, G, Mirisola, C., 2020. Negative impacts of COVID-19 lockdown on mental health service access and follow-up adherence for immigrants and individuals in socio-economic difficulties. Public Health 186, 52-56.

Armitage, R, Nellums, LB., 2020. COVID-19 and the Gypsy, Roma and Traveller population. Public Health 185, 48

Aydemir M, Akyol HB. \#Imnotavirus: Pro-Migrant Activism on Twitter Amidst the Global Corona Virus(COVID-19) Outbreak. 2020.

Bakhiet Z, Norman K, Moore Q. Building a New Life in Uncertain Times: The Impact of Covid-19 on Refugees in the US Baker Institute; 2020 2020/00.

Basso, G, Boeri, T, Caiumi, A, Paccagnella, M., 2020. The new hazardous jobs and worker reallocation. OECD Social Employment and Migration Working Papers No. 247.

Behbahani, S, Smith, CA, Carvalho, M, Warren, CJ, Gregory, M, Silva, NA., 2020. Vulnerable Immigrant Populations in the New York Metropolitan Area and COVID-19: lessons learned in the epicenter of the crisis. Acad. Med. 95 (12), 1827-1830.

Bodenmann, P, Pahud-Vermeulen, B, Bouche, L, Sanchis Zozaya, J, Bauermeister, M, Berzig, A, 2020. Left behind populations, COVID-19 and risks of health inequities: a guide of the local social-health network (Vaud, Switzerland). Revue Medicale suisse 16 (691-2), 859-862.

Bofulin, M., 2020. Chinese migrants and covid-19: Mobility and exclusion in the time of pandemic. Dve Domovini 52, 95-111.

Borjas, GJ, Cassidy, H., 2020. The Adverse Effect of the Covid-19 Labor Market Shock on Immigrant Employment. IZA Institute of Labor Economics.

Bozorgmehr, K, Hintermeier, M, Razum, O, Mohsenpour, A, Biddle, L, Oertelt-Prigione, S, et al., 2020. SARS-CoV-2 in Aufnahmeeinrichtungen und Gemeinschaftsunterkünften für Geflüchtete: Epidemiologische und normativ-rechtliche Aspekte. Kompetenznetz Public Health COVID-19, Bremen.

Brickhill-Atkinson M, Hauck FR. Impact of COVID-19 on Resettled Refugees. Primary Care: Clinics in Office Practice. 2020.

Buda, S, an der Heiden, M, Altmann, D, Diercke, M, Hamouda, O, Rexroth, U., 2020. Infektionsumfeld von erfassten COVID-19-Ausbrüchen in Deutschland. Robert Koch Institute, Berlin.

Bureau of Policy and Research. New York City's Frontline Workers. 2020.

Calderón-Larrañaga, A, Vetrano, DL, Rizzuto, D, Bellander, T, Fratiglioni, L, Dekhtyar, S., 2020. High excess mortality in areas with young and socially vulnerable populations during the COVID-19 outbreak in Stockholm Region, Sweden. BMJ Global Health 5 (10), e003595.
Canevelli, M, Palmieri, L, Raparelli, V, Punzo, O, Donfrancesco, C, Lo Noce, C, et al., 2020. COVID-19 mortality among migrants living in Italy. Ann. Ist. Super Sanita 56 (3), 373-377.

Capps R, Gelatt J. Barriers to COVID-19 testing and treatment: immigrants without health coverage in the United States. Migration policy institute; 2020 2020/00.

Carruthers E, Veizis A, Kondilis E, McCann S. SITUATIONAL BRIEF: ASYLUM SEEKERS AND REFUGEES IN GREECE DURING COVID-19. 2020.

Carruthers E, Veizis A, Kondilis E, McCann S. SITUATIONAL BRIEF: ASYLUM SEEKERS AND REFUGEES IN GREECE DURING COVID-19 (update). 2020.

Ceccarelli, G, Lopalco, M, Ettorre, G, Ettorre, G, Ciccozzi, M., 2020. Surveillance of COVID-19 in migrant reception centers: a call for action. J travel med.

Centre for British-Turkish Understanding. Emerging European Right-Wing Narratives and the Refugee Crisis in the COVID-19 Era. 2020.

Centrum for epidemiologi och samhallsmediccin RS. Socioeconomic factors for COVID-19 in the Stockholm region. 2020.

Chandratre, S, Soman, A., 2020. COVID-19 Poses Challenges to Immigrant Physicians in the United States. WMJ 119 (2), 77-78.

Chew, MH, Koh, FH, Wu, JT, Ngaserin, S, Ng, A, Ong, BC, et al., 2020. Clinical assessment of COVID-19 outbreak among migrant workers residing in a large dormitory in Singapore. J. Hosp Infect 106 (1), 202-203.

Choi, S, Hong, JY, Kim, YJ, Park, H., 2020. Predicting psychological distress amid the COVID-19 pandemic by machine learning: discrimination and coping mechanisms of Korean immigrants in the US. Int. J Environ. Res. Public Health (Online) 17 (17), 6057.

Cholera, R, Falusi, OO, Linton, JM., 2020. Sheltering in place in a xenophobic climate: COVID-19 and children in immigrant families. Pediatrics 146 (1)

Clarke, SK, Kumar, GS, Sutton, J, Atem, J, Banerji, A, Brindamour, M, et al., 2020. Potentia Impact of COVID-19 on recently resettled refugee populations in the united states and canada: perspectives of refugee healthcare providers. J. Immigr. Minor Health.

Cleveland, J, Hanley, J, Jaimes, A, Wolofsky, T., 2020. Impacts de la crise de la COVID-19 sur les « communautés culturelles » montréalaises: Enquête sur les facteurs socioculturels et structurels affectant les groupes vulnérables. Montréal: Institut universitaire SHERPA.

Cook, T, Kursumovic, E, Lennane, S., 2020. Exclusive: deaths of NHS staff from covid-19 analysed. Health Serv. J.

Cross, FL, Benson, OG., 2020. The coronavirus pandemic and immigrant communities: a crisis that demands more of the social work profession. Affilia J. Women Soc. Work.

Davis M. Impact of COVID-19 on Immigrants in Massachusetts: Insights from Our Community Survey. Massachusetts Immigrant and Refugee Advocacy Coalition; 2020 2020/00.

Dempster H, Zimmer C. Migrant Workers in the Tourism Industry: How Has COVID-19 Affected Them, and What Does the Future Hold? 2020.

Desai, S, Samari, G., 2020. COVID-19 and Immigrants; Access to Sexual and Reproductive Health Services in the United States. Perspect. Sex Reprod. Health 52 (2), 69-73.

Devillanova, C, Colombo, C, Garofolo, P, Spada, A., 2020. Health care for undocumented immigrants during the early phase of the Covid-19 pandemic in Lombardy, Italy. Eur. J Public Health ckaa205.

Dias S, Peixoto VR, Vareda R, Gama A, Abrantes A. SITUATIONAL BRIEF: COVID-19 RESPONSE \& MIGRANT HEALTH IN PORTUGAL. 2020.

Doctors of the World. An Unsafe Distance: The Impact of the COVID-19 Pandemic on Excluded People in England. 2020.

Doyle, S., 2020. Migrant workers falling through cracks in health care coverage. Can. Med. Assoc. J..

Drefahl, S, Wallace, M, Mussino, E, Aradhya, S, Kolk, M, Br, et al., 2020. A population-based cohort study of socio-demographic risk factors for COVID-19 deaths in Sweden. Nat. Commun. 11 (1), 5097

Elisabeth, M, Maneesh, PS, Michael, S., 2020. Refugees in Sweden during the COVID-19 pandemic - the need for a new perspective on health and integration. Front. Public Health 8.

Emelurumonye IN, Miglietta A. SITUATIONAL BRIEF: NEWLY ARRIVED MIGRANTS \& ASYLUM SEEKERS IN ITALY DURING THE COVID-19 PANDEMIC. 2020.

Emelurumonye IN, Miglietta A. NEW ARRIVAL MIGRANTS AND ASYLUM SEEKERS IN RECEPTION CENTRES IN ITALY DURING COVID-19 [update]. 2020.

Endale, T, St Jean, N, Birman, D., 2020. COVID-19 and refugee and immigrant youth: a community-based mental health perspective. Psychol Trauma 12, S225 -S7.

Esegbona-Adeigbe, S., 2020. COVID-19 and the risk to black, Asian and minority ethnic women during pregnancy. British J. Midwifery 28 (10), 718-723.

European Centre for Disease Prevention and Control, 2020. Guidance on Infection Prevention and Control of Coronavirus Disease (COVID-19) in Migrant and Refugee Reception and Detention Centres in The EU/EEA and the United Kingdom - June 2020 ECDC, Stockholm.

Fabiani, M, Mateo-Urdiales, A, Andrianou, X, Bella, A, Manso, MD, Bellino, S, et al., 2020. Epidemiological characteristics of COVID-19 cases in non-Italian nationals notified to the Italian surveillance system. medRxiv.

Falicov, C, Niño, A, Urso, S., 2020. Expanding possibilities: flexibility and solidarity with under-resourced immigrant families during the COVID-19 pandemic. Fam Process 59 (3), 865-882.

Falkenhain, M, Flick, U, Hirsel, A, Naji, S, Seidelsohn, K, Verlage, T., 2020. Setback in labour market integration due to the Covid-19 crisis? An explorative insight on forced migrants' vulnerability in Germany. Eu. Soc.

Fitzpatrick, KM, Harris, C, Drawve, G., 2020. Fear of COVID-19 and the mental health consequences in America. Psychol. Trauma 12, S17 -S21.

Garrote Sanchez D, Gomez Parra N, Ozden C, Rijkers B. Which Jobs Are Most Vulnerable to COVID-19? What an Analysis of the European Union Reveals. Research and Policy Brief; No. 34. World Bank, Washington, DC. 2020. 
Germain, S, Yong, A., 2020. COVID-19 highlighting inequalities in access to healthcare in england: a case study of ethnic minority and migrant women. Fem Leg Stud. 1-10.

Gilman, RT, Siyana, M-S, Christian, H, Andrew, TC., 2020. Modelling interventions to control COVID-19 outbreaks in a refugee camp. medRxiv.

Giordano C. Freedom or money? The dilemma of migrant live-in elderly carers in times of COVID-19. Gender, work and organization. 2020.

Giorgi Rossi, P, Marino, M, Formisano, D, Venturelli, F, Vicentini, M, Grilli, R, 2020. Characteristics and outcomes of a cohort of COVID-19 patients in the Province of Reggio Emilia. Italy. PLoS One. 15 (8), e0238281 -e.

Goodman, J, Wang, SX, Rubi, AGO, Santana, MH., 2020. Mental health of undocumented college students during the COVID-19 pandemic. medRxiv.

Gosselin A, Loû ADed, Casella-Colombeau S, Vignier N, Melchior M. SITUATIONAL BRIEF: THE HEALTH OF ASYLUM SEEKERS \& UNDOCUMENTED MIGRANTS IN FRANCE DURING COVID-19. 2020.

Gottlieb N, Hintermeier M, Bozorgmehr K. SITUATIONAL BRIEF: COVID-19 \& MIGRATION IN GERMANY. 2020.

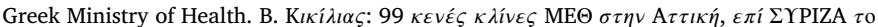

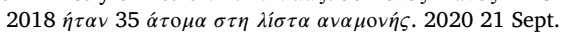

Green, AS, Ruchman, SG, Katz, CL, Singer, EK., 2020. Piloting forensic tele-mental health evaluations of asylum seekers. Psychiatry Res. 291, 113256

Greenaway, C, Hargreaves, S, Barkati, S, Coyle, CM, Gobbi, F, Veizis, A, et al., 2020. COVID-19: Exposing and addressing health disparities among ethnic minorities and migrants. J. Travel Med. 27 (7), taaa113.

Grilli, R, Marino, M, Formisano, D, Costantini, M, Formoso, G, Bedeschi, M, et al., 2020. Prevalenza di infezione SARS-CoV-2 (Covid-19) negli italiani e negli immigrati nell'area di Reggio Emilia. Epidemiol Prev. 44 (4), 304-307.

Guadagno, L., 2020. Migrants and the COVID-19 pandemic: an initial analysis. IOM.

Guijarro, C, Pérez-Fernández, E, González-Piñeiro, B, Meléndez, V, Goyanes, MJ, Renilla, ME, et al., 2020. Increased risk for COVID-19 among migrants from Latin-America, Caribbean, and Sub-Saharan Africa living in Spain. medRxiv.

Guo, M, Joanpere, M, Pulido, C, Padrós Cuxart, M, 2020. Coping of Chinese citizens living in Spain during the COVID-19 pandemic: lessons for personal well-being and social cohesion. Sustainability 12 (19), 7949.

Guttmann, A, Gandhi, S, Wanigaratne, S, Lu, H, Ferreira-Legere, L, Paul, J, et al., 2020. COVID-19 in Immigrants, Refugees and Other Newcomers in Ontario: Characteristics of Those Tested and Those Confirmed Positive, as of June 13, 2020. ICES, Toronto, ON.

Haley, E, Caxaj, S, George, G, Hennebry, JL, Martell, E, McLaughlin, J., 2020. Migrant farmworkers face heightened vulnerabilities during COVID-19. J. Agri. Food Syst. Commun. Develop. 9 (3).

Hamadah H, AB, Behbehani, M, et al., 2020. COVID-19 clinical outcomes and nationality: results from a Nationwide registry in Kuwait. BMC Public Health 20.

Hansson, E, Albin, M, Rasmussen, M, Jakobsson, K., 2020. [Large differences in excess mortality in March-May 2020 by country of birth in Sweden]. Lakartidningen 117, 20113.

Hargreaves, S, Zenner, D, Wickramage, K, Deal, A, Hayward, SE., 2020. Targeting COVID-19 interventions towards migrants in humanitarian settings. Lancet Infect. Dis. 20 (6), 645-646.

Hargreaves, S, Kumar, BN, McKee, M, Jones, L, Veizis, A., 2020. Europe's migrant containment policies threaten the response to covid-19. BMJ 368, m1213-m.

Hernandez-Suarez, CM, Verme, P, Radyakin, S, Murillo-Zamora, E., 2020. COVID-19 outbreaks in refugee camps. A simulation study. medRxiv.

Iacobucci, G., 2020. Covid-19: Doctors warn of humanitarian catastrophe at Europe's largest refugee camp. BMJ 368, m1097 -m.

Institut for Menneskerettigheder. Corona rammer skævt - etnicitet og smitte. Copenhagen, Denmark; 2020.

Irvine, M, Coombs, D, Skarha, J, Del Pozo, B, on, Rich, J, et al., 2020. Modeling COVID-19 and Its impacts on US immigration and customs enforcement (ICE) detention facilities, 2020. J. Urban Health 97 (4), 439-447.

Júnior, JG, de Sales, JP, Moreira, MM, Pinheiro, WR, Lima, CKT, Neto, MLR., 2020. A crisis within the crisis: The mental health situation of refugees in the world during the 2019 coronavirus (2019-nCoV) outbreak. Psychiatry Res. 288, 113000

Jaqueti Aroca, J, Molina Esteban, LM, García-Arata, I, García-Martínez, J, 2020. COVID-19 en pacientes españoles e inmigrantes en un área sanitaria de Madrid. Rev. Esp. Quimioter 33 (4), 289-291.

Jauhiainen, J., 2020. Biogeopolitics of COVID-19: asylum-related migrants at the European Union Borderlands. Tijdschr Econ Soc. Geogr. 111 (3), 260-274.

Joanna Briggs Institute. The Joanna Briggs Institute Critical Appraisal Tools. Available at: https://joannabriggs.org/critical-appraisal-tools. 2020.

Jozaghi, E, Dahya, A., 2020. Refugees, asylum seekers and COVID-19: Canada needs to do more to protect at-risk refugees during the current pandemic. Can J. Public Health 111 (3), 413-414.

Kanlungan Filipino Consortium. "A chance to feel safe": Precarious Filipino migrants amid the UK's coronavirus outbreak. 2020.

Kerwin, D, Warren, R., 2020. US foreign-born workers in the global pandemic: essential and marginalized. J. Migr. Human Security 1-19.

Kim, HN, Lan, KF, Nkyekyer, E, Neme, S, Pierre-Louis, M, Chew, L, et al., 2020. Assessment of Disparities in COVID-19 Testing and Infection Across Language Groups in Seattle, Washington. JAMA Netw Open 3 (9), e2021213 -e.

Kondilis, E, Puchner, K, Veizis, A, Papatheodorou, C, Benos, A., 2020. Covid-19 and refugees, asylum seekers, and migrants in Greece. BMJ 369, m2168 -m.

Kong, YJ, Shaver, LG, Shi, FY, Yang, LX, Zhang, WG, Wei, XL, et al., 2020. Belief and Usage of traditional Chinese medicine as preventative measure against COVID-19 infection during the pandemic among Chinese immigrants in Canada. Ann. Epidemiol. 52, 105.

Kuhlmann, E, Falkenbach, M, Klasa, K, Pavolini, E, Ungureanu, M-I., 2020. Migrant car- ers in Europe in times of COVID-19: a call to action for European health workforce governance and a public health approach. Eur. J. Public Health 30, iv22 -iv7.

Kunst, A, Md, Visser, Stoeldraijer, L, Harmsen, C, 2020. Oversterfte tijdens de eerste zes weken van de corona-epidemie: Sociaal-demografische en geografische verschillen. Centraal Bureau voor de Statistiek.

Lam, E., 2020. Migrant sex workers left behind during COVID-19 pandemic. Can J. Public Health 111 (4), 482-483.

Langellier, BA., 2020. Policy recommendations to address high risk of COVID-19 among immigrants. Am. J. Public Health 110 (8), 1137-1139.

Lee, JGL, LePrevost, CE, Harwell, EL, Bloss, JE, Cofie, LE, Wiggins, MF, et al., 2020. Coronavirus pandemic highlights critical gaps in rural Internet access for migrant and seasonal farmworkers: a call for partnership with medical libraries. J. Med. Libr. Assoc. 108 (4), 651-655.

Lenzer, J., 2020. Mass hysterectomies' were carried out on migrants in US detention centre, claims whistleblower. BMJ 370, m3615 -m.

Logar S, Leese M. Childhood detention during COVID-19 in Italy: building momentum for a comprehensive child protection agenda. International health (Online). 2020

Lopez, MM, Holmes, SM., 2020. Raids on immigrant communities during the pandemic threaten the country's public health. Am. J. Public Health 110 (7), 958-959.

Mares, T., 2020. What a stay-at-home order means for migrant dairy workers. Agric. Human Values 1-2.

Mathur, R, Bear, L, Khunti, K, Eggo, RM., 2020. Urgent actions and policies needed to address COVID-19 among UK ethnic minorities. Lancet North Am. Ed. 396 (10266).

Mattar, S, Piwowarczyk, LA., 2020. COVID-19 and U.S.-based refugee populations. Commentary. Psychol. Trauma. 12, S228 -S9.

Medact. Exploring Migrant Access to Health: Part 2 - Prioritisation of COVID-19 testing: Migrant camps must not be forgotten. 2020.

Meyer, JP, Franco-Paredes, C, Parmar, P, Yasin, F, Gartl, M., 2020. COVID-19 and the coming epidemic in US immigration detention centres. Lancet Infect Dis 20 (6), 646-648.

Migration Data Portal. Migration data relevant for the COVID-19 pandemic. 2020.

Ministry of Health Saudi Arabia. The Press Conference of the Official Spokesperson of Ministry of Health on the Novel Coronavirus. 7 May 2020.

Ministry of Health Singapore. Ministry of Health, Singapore, Government Agency Website 2020 [Available from: https://www.moh.gov.sg/covid-19/situation-report.

Moher, D, Liberati, A, Tetzlaff, J, Altman, DG, 2009. The PRISMA group. Preferred reporting items for systematic reviews and meta-analyses: the PRISMA statement. PLoS Med. 6 (7), e1000097.

Mosca DT, Marotta C, Gennaro FD, Putoto G, D'Alessandro M, Bhopal R. SITUATIONAL BRIEF: DEPORTATIONS AND IRREGULAR MIGRANTS DURING THE COVID-19 PANDEMIC. 2020.

Motta, I, Centis, R, Ambrosio, L, García-García, JM, Goletti, D, Gualano, G, et al., 2020. Tuberculosis, COVID-19 and migrants: preliminary analysis of deaths occurring in 69 patients from two cohorts. Pulmonology 26 (4), 233-240.

Mupenzi, A, Mude, W, Baker, S., 2020. Reflections on COVID-19 and impacts on equitable participation: the case of culturally and linguistically diverse migrant and/or refugee (CALDM/R) students in Australian higher education. High Educ. Res. Dev. 39 (7).

Nezafat Maldonado, B, Collins, J, Blundell, HJ, Singh, L, 2020. Engaging the vulnerable: a rapid review of public health communication aimed at migrants during the COVID-19 pandemic in Europe. J. Migr. Health 1-2, 100004.

Nicholson M, Alulema D. Immigrants comprise 31 percent of workers in New York state essential businesses and 70 percent of the state's undocumented labor force works in essential businesses. the center for migration studies of New York (CMS); 2020.

Nobody Left Outside. COVID-19 in marginalised groups: challenges, actions and voices. August 2020.

Noori, T, Hargreaves, S, Greenaway, C, van der Werf, M, Driedger, M, Morton, RL, et al., 2020. Strengthening screening for infectious diseases and vaccination among migrants in Europe: What is needed to close the implementation gaps? Travel Med. Infect. Disease, 101715.

Norweigan Institute of Public Health [Folkehelseinstituttet]. Covid-19-epidemien: kunnskap, situasjon, prognose, risiko og respons i Norge etter uke 18. 5. mai 2020a.

Norweigan Institute of Public Health [Folkehelseinstituttet]. Kunnskap, situasjon, prognose, risiko og respons i Norge etter uke 45. 5. november 2020b.

Observatoire Regional de Sante Ile de France. La surmortalite durant l'epidemie de Covid19 dans les departements franciliens. 2020.

OECD. What is the impact of the COVID-19 pandemic on immigrants and their children? 2020.

Openshaw JJ, Travassos MA. COVID-19 outbreaks in U.S. immigrant detention centers: the urgent need to adopt CDC guidelines for prevention and evaluation. 2020.

Orcutt, M, Patel, P, Burns, R, Hiam, L, Aldridge, R, Devakumar, D, et al., 2020. Global call to action for inclusion of migrants and refugees in the COVID-19 response. Lancet 395 (10235), 1482-1483.

Ouzzani, M, Hammady, H, Fedorowicz, Z, Elmagarmid, A., 2016. Rayyan-a web and mobile app for systematic reviews. Syst. Rev. 5 (1), 210.

Pacheco, T, Coulombe, S, Khalil, C, Meunier, S, Doucerain, M, Auger, E, et al., 2020. Job security and the promotion of workers' wellbeing in the midst of the covid-19 pandemic: A study with canadian workers one to two weeks after the initiation of social distancing measures. Int. J. Wellbeing 10 (3).

Page, KR, Venkataramani, M, Beyrer, C, Polk, S., 2020. Undocumented US immigrants and COVID-19. N. Eng. J. Med. 382 (21), e62 -e.

Papon S, Robert-Bobée I. Une hausse des décès deux fois plus forte pour les personnes nées à l'étranger que pour celles nées en France en mars-avril 2020 [Available from: https://www.insee.fr/fr/statistiques/4627049\# consulter.

Patel P, Hiam L, Orcutt M, Burns R, Devakumar D, Aldridge R, et al. Policy brief: Including migrants and refugees in the British government's response to COVID-19. 2020.

Paul, E, Steptoe, A, Fancourt, D., 2020. Anti-vaccine attitudes and risk factors for not 
agreeing to vaccination against COVID-19 amongst 32,361 UK adults: Implications for public health communications. medRxiv 2020.10.21.20216218.

Peprah, P., 2020. Ageing out of place in COVID-19 pandemic era: How does the situation look like for older refugees in camps? Arch. Gerontol. Geriatr 90, 104149 -

Pinzón-Espinosa, J, Valdés-Florido, MJ, Riboldi, I, Baysak, E, Vieta, E., 2020. The COVID-19 pandemic and mental health of refugees, asylum seekers, and migrants. J. Affect. Disord.

Potter, JL, Burman, M, Tweed, CD, Vaghela, D, Kunst, H, Swinglehurst, D, et al., 2020. The NHS visitor and migrant cost recovery programme - a threat to health? BMC Public Health 20 (1), 407.

Primdahl, NL, Borsch, AS, Verelst, A, Jervelund, SS, Derluyn, I, Skovdal, M., 2020. 'It's difficult to help them when I am not sitting next to them': How COVID-19 school closures interrupted teachers' care for newly arrived migrant and refugee learners in Denmark. Vulnerable Children and Youth Studies.

Public Health England. Disparities in the risk and outcomes of COVID-19. 2020.

Ramírez-Cervantes, KL, Romero-Pardo, V, Pérez-Tovar, C, Martínez-Alés, G, QuintanaDiaz, M., 2020. A medicalized hotel as a public health resource for the containment of COVID-19: more than a place for quarantining. J. Public Health (Oxf).

Rizzolo, K, Novick, TK, Cervantes, L., 2020. Dialysis care for undocumented immigrants with kidney failure in the COVID-19 era: public health implications and policy recommendations. Am. J. Kidney Dis. 76 (2), 255-257.

Roederer, T, Mollo, B, Vincent, C, Nikolay, B, Llosa, A, Nesbitt, R, et al., 2020. High seroprevalence of SARS-CoV-2 antibodies among people living in precarious situations in Ile de France. medRxiv 2020.10.07.20207795.

Rostila, M, Cederström, A, Wallace, M, Brandén, M, Malmberg, B, Andersson, G., 2020. Disparities in covid-19 deaths by country of birth in Stockholm, Sweden: a total population based cohort study. Stockholm Res. Rep. Demogr. 39.

Rush, N., 2020. Refugee Placement and Medical Concerns Amid a Covid-19 Pandemic and an Economic Crisis. Center Immigr. Studies.

Sabri, B, Hartley, M, Saha, J, Murray, S, Glass, N, Campbell, JC., 2020. Effect of COVID-19 pandemic on women's health and safety: a study of immigrant survivors of intimate partner violence. Health Care Women Int. 1-19.

Santos, G-M, Ackerman, B, Rao, A, Wallach, S, Ayala, G, Lamontage, E, et al., 2020. Economic, mental health, HIV prevention and HIV treatment impacts of COVID-19 and the COVID-19 response on a global sample of cisgender gay men and other men who have sex with men. AIDS Behav. 1-11.

Sarrica, F, Healy, C, Serio, G, Samson, J., 2020. How COVID-19 restrictions and the economic consequences are likely to impact migrant smuggling and cross-border trafficking in persons to Europe and North America. UNODC.

Schotland, SD., 2020. A plea to apply principles of quarantine ethics to prisoners and immigration detainees during the COVID-19 crisis. J. Law Biosci. 7 (1).

Silverman, M, Sibbald, R, Stranges, S., 2020. Ethics of COVID-19-related school closures. Can. J. Public Health 111 (4), 462-465.

Spernovasilis, N, Markaki, L, Tsioutis, C., 2020. Challenges posed by covid-19 to refugee camps on the Greek islands: we are all humans after all. Pneumon.

St-Denis, X., 2020. Sociodemographic determinants of occupational risks of exposure to COVID-19 in Canada. Can. Rev. Sociol. 57 (3), 399-452.

Statens Serum Institut. Epidemiologisk trend og fokus: Herkomst (etnicitet). Copenhagen, Denmark; 2020.

Statens Serum Institut, 2020. COVID-19 og herkomst - opdateret fokusrapport. Copenhagen, Denmark.

Strully, K, Yang, T-C, Liu, H., 2020. Regional variation in COVID-19 disparities: connections with immigrant and Latinx communities in US counties. Ann. Epidemiol. 53, 56-62.e2.

Sundaram, M, Calzavara, A, Mishra, S, Kustra, R, Chan, A, Hamilton, MA, et al., 2020. The Individual and social determinants of COVID-19 in Ontario, Canada: a population-wide study. medRxiv.

Swedish Public Health Agency (Folkhälsomyndigheten). Demographic Description of Confirmed Covid-19 Cases in Sweden from 13 March to 7 May (in Swedish, Demografisk Beskrivning av Bekräftade Covid-19 Fall i Sverige 13 Mars-7 maj 2020). 2020.

Sze S, PD, Nevill, CR, et al., 2020. Ethnicity and clinical outcomes in COVID-19: a systematic review and meta-analysis. EClinicalMedicine, 100630.

Tadolini, M, Codecasa, LR, García-García, J-M, Blanc, F-X, Borisov, S, Alffenaar, J-W, et al., 2020. Active tuberculosis, sequelae and COVID-19 co-infection: first cohort of 49 cases. Eur. Respir. J. 56 (1).
Tayaben, JL, Younas, A., 2020. Call to action for advocacy of immigrant nurses during COVID-19 pandemic. J. Adv. Nurs. 76 (9), 2220-2221.

The Lancet, 2020. COVID-19 will not leave behind refugees and migrants. Lancet. 395 (10230), 1090 -

The Migrant and Ethnic Health Section of the European Public Health Association (EUPHA). Statement by the EUPHA Migrant and ethnic minority health section on COVID-19 - CALL FOR ACTION. https://eupha.org/repository/advocacy/ MIG_statement_on_COVID19.pdf. 2020.

Platform for International Cooperation on Undocumented Migrants. The COVID-19 pandemic: we need urgent measures to protect people and mend the cracks in our health, social protection and migration systems. https://picumorg/wp-content/ uploads/2020/03/COVID-19-Statement-March-2020.pdf. 2020.

Turcotte, M, Savage, K., 2020. The contribution of immigrants and population groups designated as visible minorities to nurse aide, orderly and patient service associate occupations. Statistics Canada.

UNHCR, IOM, OHCHR, WHO. The rights and health of refugees, migrants and stateless must be protected in COVID-19 response: A joint statement. 2020.

Valeriani, G, Sarajlic Vukovic, I, Lindegaard, T, Felizia, R, Mollica, R, Andersson, G, 2020. Addressing healthcare gaps in sweden during the COVID-19 outbreak: on community outreach and empowering ethnic minority groups in a digitalized context. Healthcare (Basel) 8 (4).

Valeriani, G, Vukovic, IS, Lindegaard, T, Felizia, R, Mollica, R, Andersson, G., 2020. Unconventional answers to unprecedented challenges: the Swedish experience during the COVID-19 outbreak. J Prev Med Public Health 53 (4), 233-235.

Veizis, A., 2020. Leave no one behind" and access to protection in the Greek Islands in the COVID-19 era. Int. Migr. 58 (3), 264-266.

Vonen, HD, Olsen, ML, Eriksen, SS, Jervelund, SS, Eikemo, TA., 2020. Refugee camps and COVID-19: Can we prevent a humanitarian crisis? Scand J. Public Health.

Wang, F, Tian, C, Qin, W., 2020. The impact of epidemic infectious diseases on the wellbeing of migrant workers: a systematic review. Int. J. Wellbeing 10 (3).

Wang, S, Chen, X, Li, Y, Luu, C, Yan, R, Madrisotti, F., 2020. 'I'm More Afraid of Racism Than of the Virus!': Racism Awareness and Resistance Among Chinese Migrants and Their Descendants in France During the COVID-19 Pandemic. European Societies, pp. 1-22.

Warner, G, Keeshin, B, Sarkadi, A., 2020. Mapping trauma support onto the shifting landscape of seeking refuge in Sweden: insights from an ongoing programme of research on refugee minors' mental health. Eur Child. Adolesc. Psychiatry 1-2.

Wernly, B, Wernly, S, Magnano, A, Paul, E., 2020. Cardiovascular health care and health literacy among immigrants in Europe: a review of challenges and opportunities during the COVID-19 pandemic. Z Gesundh Wiss 1-7.

Wilson, DB, Solomon, TA, McLane-Davison, D., 2020. Ethics and racial equity in social welfare policy: social work's response to the COVID-19 pandemic. Soc. Work Public Health 35 (7), 617-632.

Wong CL, CJ, Chow, KM, et al., 2020. Knowledge, attitudes and practices towards COVID-19 amongst ethnic minorities in Hong Kong. Int. J. Environ. Res. Public Health (Online) 17 (21)

Wood, LCN, Devakumar, D., 2020. Healthcare access for migrant children in England during the COVID-19 pandemic. BMJ Paediatr Open 1 (4).

Yeung, E, Hopkins, P, Auzinger, G, Fan, K., 2020. Challenges of tracheostomy in COVID-19 patients in a tertiary centre in inner city London. Int. J. Oral Maxillofac. Surg. 49 (11), 1385-1391.

Zajacova, A, Jehn, A, Stackhouse, M, Denice, P, Ramos, H., 2020. Changes in health behaviours during early COVID-19 and socio-demographic disparities: a cross-sectional analysis. Can J. Public Health 1-10.

Zelaya L, Moore Q, Lizette Cruz P. Undocumented and Unprotected: Health Challenges for Immigrants During the Covid-19 Pandemic. Baker Institute; 2020 2020/00.

Zero, O, Geary, M., 2020. COVID-19 and intimate partner violence: a call to action. Rhode Island Med. J. (2013) 1 (103), 57-59.

Zhang, L-T, Zhao, S., 2020. Diaspora micro-influencers and COVID-19 communication on social media: the case of Chinese-speaking YouTube vloggers. Multilingua-J. CrossCultural Interlanguage Commun. 39 (5). 